OPEN ACCESS

Edited by:

Yasser Khazaal,

Université de Genève, Switzerland

Reviewed by:

Jacqueline Sin,

University of Reading, United Kingdom

Shervin Assari,

University of Michigan, United States

${ }^{*}$ Correspondence:

Nadia N. Abuelezam

nadia.abuelezam@bc.edu

Specialty section:

This article was submitted to

Public Mental Health,

a section of the journal

Frontiers in Public Health

Received: 03 May 2018

Accepted: 22 August 2018

Published: 11 September 2018

Citation:

Abuelezam NN, El-Sayed AM and Galea S (2018) The Health of Arab Americans in the United States: An Updated Comprehensive Literature Review. Front. Public Health 6:262. doi: 10.3389/fpubh.2018.00262

\section{The Health of Arab Americans in the United States: An Updated Comprehensive Literature Review}

\author{
Nadia N. Abuelezam ${ }^{1 *}$, Abdulrahman M. El-Sayed ${ }^{2}$ and Sandro Galea ${ }^{3}$ \\ ${ }^{1}$ Boston College, William F. Connell School of Nursing, Chestnut Hill, MA, United States, ${ }^{2}$ Department of Health, Detroit, MI, \\ United States, ${ }^{3}$ School of Public Health, Boston University, Boston, MA, United States
}

Background: Arab Americans are a historically understudied minority group in the United States and their health needs and risks have been poorly documented. We aim to provide an updated comprehensive review of the literature on Arab American physical and mental health and provide suggestions for future work in this field.

Methods: A comprehensive review of the English language medical and public health literature published prior to 2017 identified through multiple database searches was conducted with search terms describing Arab Americans and health outcomes and behaviors. The literature was qualitatively summarized by health behavior (vaccination, tobacco use, drug and alcohol use, and physical activity), health outcome (diabetes, mental health, cardiovascular disease, cancer, women's, and child health), and populations at increased risk of poor health outcomes (adolescents and the elderly).

Results: The majority of studies identified exploring Arab American health have been published since 2009 with an increase in the number of longitudinal and intervention studies done with this population. The majority of research is being undertaken among individuals living in ethnic enclaves due to the lack of an ethnic or racial identifier that may help identify Arab Americans from population-based studies. Studies highlight the conflicting evidence in the prevalence of diabetes and cardiovascular disease based on study sample, an increased understanding of cancer incidence and barriers to identification, and an increased level of knowledge regarding mental health and sexual health needs in the population. Information on health behaviors has also increased, with a better understanding of physical activity, alcohol and drug use, and vaccination.

Conclusion: More research on Arab American health is needed to identify risks and needs of this marginalized population given the current social and political climate in the United States, especially with regard to acculturation status and immigrant generation status. We provide recommendations on approaches that may help improve our understanding of Arab American health.

Keywords: health disparities, arab american, stress, diabetes, mental health, women's health, child health, infectious disease 


\section{INTRODUCTION}

Race and ethnicity are a dominant part of national and academic conversations in the United States. One group that is historically represented but largely absent from national and academic conversations about race and ethnicity are Arab Americans. Arab Americans' classification within the United States' racial schema as White makes them invisible as a minority group. This is at odds with politics, war, and violence in the Middle East and the stigmatizing representation of Arabs in the media. Additionally, a recent report by the Arab American Institute Foundation has found that in line with the general surge of biasmotivated violence in the past few years, Arab Americans are at increased risk for hate crimes (1). This discrepancy between having a highly visible and stigmatized group that also has a general lack of visibility in official documents or health records places Arab Americans in an unusual position in the American healthcare system - they are a group that both exists in the public consciousness but is also un-counted and hence has not been a part of a national reckoning with its needs and particularities (2). Aiming to address this gap, we set out to comprehensively review the Arab American health literature, updating a previous review that was conducted a decade ago (3). We examine literature on the health behaviors (actions taken to maintain, attain, or regain good health and prevent illness), health outcomes (an illness, condition, or state that impacts the length or quality of a person's life), and sub-populations within the large Arab American population with particular health needs.

Arab Americans are those individuals with ancestral, cultural, ethnic, linguistic, familial, or heritage ties to one or more of the 22 Arab League countries. It is estimated that there are approximately 3.5 million Arab Americans living in the United States (4). Arabs are disproportionately represented among recent immigrants to the United States due to war and instability in the Middle East. The diversity in country of origin of Arab immigrants makes understanding health indicators difficult, as the differences in health outcomes among Arabic League countries can be disparate. Social determinants in these countries vary dramatically from high poverty and war torn to highly affluent and stable. Arab Americans have varied nativity in the United States: foreign-born (first generation), U.S. born children of immigrants (1.5 and second generation), or U.S. born to U.S. born parents (third and greater generations) (5). The diversity in country of origin, geographic location, tenure in the United States, and acculturation makes studying Arab Americans difficult and the task of generally understanding Arab American health monumental.

A history of Arab American immigration to the United States has been published elsewhere (6). Prior to the 1940's the position of Arab immigrants in the United States' racial system was unclear if not ambiguous (2). The Census Bureau decided in the 1940's that Arab Americans were to be treated like other European immigrant communities (7). The Office of Management and Budget of the United States government has outlined that Arab Americans belong to the "White" racial category, as having origins from the Middle East (8). Arab American's place in society was complicated by developments in the Middle East that led to increased discrimination and exclusion of this population since the 1960's and 1970's (1). Arab American organizations and community members began advocating for a dedicated Middle East and North African (MENA) identifier on the U.S. Census in the 1990's (9). A test of this category was done on the 2015 Census but recently the U.S. Census decided not to include the MENA category on the 2020 Census ${ }^{1}$.

The aim of this review is to provide an updated assessment of the peer-reviewed literature concerned with the health of Arab Americans living in the United States and to summarize key health indicators in this population. A previous review of Arab American health literature published in 2009 reviewed 34 research studies and found little consensus regarding the burden of cardiovascular disease and diabetes in Arab Americans, little information about cancer or mental health disorders, and mixed information regarding whether social determinants of health differed for Arab Americans when compared to other populations (3). We aim to update this review with information on more recently published studies in this population and to synthesize current knowledge about health risks facing Arab Americans to better inform interventions for this vulnerable population and to encourage additional research.

\section{METHODS}

The main aim of this study is to summarize the state of the medical and public health literature describing the mental and physical health outcomes and needs of Arab Americans published prior to January 1, 2017. We conducted a comprehensive review following many of the reporting guidelines and criteria set forth by the Preferred Reporting Items of Systematic Reviews (PRISMA) (10). A search was conducted using PubMed/Medline, BIOSYS Previews, CINAHL, Cochrane Reviews, and Web of Science on Arab Americans (specified by a combination of terms including country of origin and regional identifiers) and health related outcomes including tobacco use, cardiovascular disease, stroke, cancer, diabetes, maternal and child health, depression, mental health, trauma, substance abuse and general mental and physical health terms (Supplemental Material). These health behaviors and outcome categories were chosen based on the outcomes most prevalently represented in the previous review and on the authors' expertise. For inclusion, articles needed to describe a study in a population of Arab Americans in the United States. Studies also needed to include a health outcome (defined broadly as physical or mental well-being), be written in English, and be published before January 1, 2017. Qualitative and quantitative research studies were included. Endnote (X8) was the bibliographical data management software used for this review.

After removing duplicates, each article's title and abstract were read and evaluated by two members of the research team against the inclusion criteria set above. Articles that did not meet the

\footnotetext{
${ }^{1}$ Using Two Separate Questions for Race and Ethnicity in 2018 End-to-End Census: Hearing before the 2020 Census Program Memorandum Series (February $2,2018,2018$ )
} 
criteria were excluded after conferring with a third research team member. Based on the evaluation process with the titles and abstracts, 7424 articles were removed yielding 445 articles (Figure 1). Full texts of 445 articles were evaluated to ensure each article was a true match to the study criteria. This resulted in the further exclusion of 198 articles, yielding 247 articles in the review. All decisions were agreed upon through review and consensus by at least three research team members (Figure 1).

Epidemiological information on study design, sampling characteristics, study period, geographic origin of samples, and study location were extracted from all papers by multiple investigators. When estimates of prevalence or incidence were reported across studies for the same health outcome, these estimates were recorded as a range. Data points that provided an understanding of the magnitude of illness or disease in Arab Americans were extracted along with notable study designs and observations from qualitative studies. Results are summarized descriptively to help inform readers of the most rigorous, generalizable, and notable takeaways from studies with large sample sizes and rigorous sampling frames (when possible) within health outcomes, behaviors, and vulnerable populations. Quality of data and potential for bias was assessed epidemiologically by more than one investigator and notable exceptions (both positive and negative) are described descriptively within each outcome section of the Results and the Discussion. Due to the heterogeneity in study type and quality of the Arab American literature a systematic quality assessment was not conducted.

\section{RESULTS}

Since the publication of the last review 169 papers were published accounting for $68 \%$ of all publications reviewed. We organized our findings around health behaviors, health outcomes, and populations of interest. We examined health behaviors among Arab Americans including tobacco use, physical activity, alcohol and drug use, and vaccination. We examined seven morbidity clusters for health outcomes including diabetes, mental health, women's and child health, cancer, cardiovascular disease, and other health outcomes. Finally, we highlighted two distinct populations of interest for Arab American health: adolescents and the elderly.

Papers describing the health of Somali immigrants and their descendants in the United States $(N=66,27 \%)$ accounted for the largest immigrant subgroup, while Iraqi immigrants $(N=39$, $16 \%)$ accounted for the second largest identified subgroup. Nearly half of all papers examined the health of a mix of countries of origin or did not specify the composition of the groups they included $(N=122,49 \%)$. The number of United States cities and regions in which Arab American health research is taking place has expanded since the last review. While the majority of studies were still being undertaken in Michigan $(N=90,36 \%)$, many other states are represented in the literature including Minnesota $(N=30,12 \%)$, California $(N=11,5 \%)$, New York $(N=8,3 \%)$ and Virginia $(N=4,2 \%)$. Eight studies have examined national samples of Arab Americans (3\%) while some examined Arab Americans from multiple cities $(N=9,4 \%)$.

The epidemiologic composition of publications examined has shifted dramatically since the last review was written. The number of studies testing interventions $(N=15,6 \%)$ and the number of longitudinal studies $(N=30,12 \%)$ among Arab Americans increased since 2009. Novel methodologies like snowball sampling $(N=13,5 \%)$ and web-based surveys $(N=3$, $1 \%)$ were also used in addition to more traditional qualitative methods like focus groups $(N=77,31 \%)$. The majority of the literature focused on describing health outcomes in a sample $(N=136,55 \%)$ as opposed to examining the relationship between an exposure and outcome.

\section{Health Behaviors Tobacco Use}

Research regarding tobacco use and addiction among Arab Americans has had a strong foothold and publishing record in Arab American health literature since the early 1990's. The first study on Arab American smoking prevalence occurred in 1992 and aimed to estimate community prevalence among Arab Americans (38.9\%) in Michigan (11). Since that first study was published, a number of other studies have examined the prevalence of smoking among Arab American populations, primarily in the Michigan area $(12,13)$, but also in Houston, Minnesota, and Virginia (14-16) with smoking prevalence ranging from 6 to $45 \%$. Generally, it has been found that less assimilated Arab Americans had a higher dependence on nicotine and tobacco products with the use of tobacco correlating negatively with time spent in the United States (17). More recent literature aims to understand the predictors of waterpipe smoking and of quitting smoking in Arab American populations. Generally, very little evidence was found that Arab Americans desire to quit water-pipe smoking (14). An intervention study performed in a Midwest school aimed at discouraging high school students from starting smoking or continuing smoking showed improvements in non-Arab American and Arab American teens (18).

\section{Physical Activity}

Most of the studies on physical activity were from small convenience samples often performed at religious sites or from religious communities. Further, many of these samples were taken from ethnic enclaves and areas where a large number of Arab immigrants live. Some studies have examined the impact of acculturation on physical activity and found that individuals with lower American acculturation tended to have less physical activity (19) while those found to be more acculturated participated in more physical activities (20). Further, some barriers to physical activity have been identified including a lack of knowledge about how to use machines at the gym (21), lack of money for gym memberships (22), and mixed cultural messaging on body image (19).

\section{Alcohol and Drug Use}

A study aimed at estimating the prevalence of binge drinking among Arab Americans at both national and state levels found 


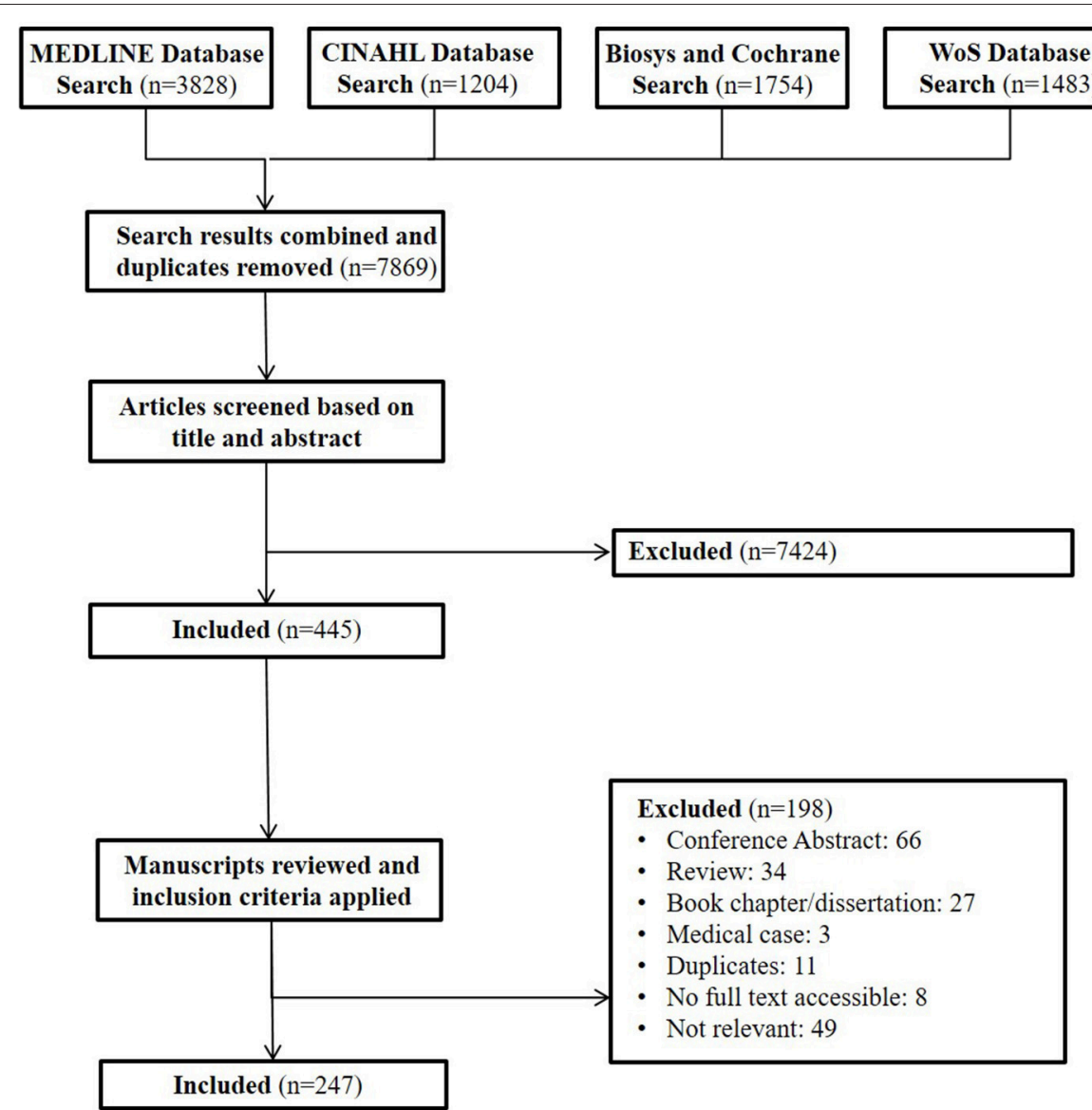

FIGURE 1 | Review cascade for Arab American health. This cascade describes the process through which papers were identified and reviewed for our comprehensive review of Arab American health in the public health and medical literature.

that nationally Arab Americans had lower prevalence of lifetime alcohol consumption and consumption in the last month than non-Hispanic Whites (23). The national data also showed that Arab American men were 1.78 times more likely to have had alcohol in their lifetime than women (23). An exploratory qualitative study performed by the same investigators aimed to understand the potential reasons for this discrepancy found that alcohol was easily accessible in Arab American communities and environments in Michigan, that social pressures encouraged people to drink at social gatherings, and that populations that were more highly acculturated tended to have higher drinking prevalence than those who were not (24). Some research has been done to understand the low representation of Arab Americans in substance abuse treatment and the presence of language and cultural barriers to Arab Americans enrolling in these programs was uncovered (25).

\section{Vaccination}

Research on vaccination behavior among Arab Americans lags behind our knowledge of vaccination behavior in other immigrant and minority groups (26-28). A study with data from a national health survey found that Arab Americans had lower estimated rates of recommended vaccinations (flu and pneumonia) when compared to non-Hispanic Whites (29). Only one study among Somali adolescents in Minnesota examined the uptake of human papilloma virus vaccinations. This study showed that while Somali adolescents were accepting of the vaccine, they were less likely to complete the vaccine series when compared to non-Arab, non-Hispanic Whites in the same area (30).

\section{Morbidity Clusters \\ Diabetes}

Estimates of diabetes prevalence in Arab American populations range from 4.8 to $23 \%(31-33)$. Due to the high prevalence of diabetes and higher odds of diabetes when compared to non-Arab, non-Hispanic Whites found in many Arab American populations, including Somali Americans (34), researchers have examined biological and genetic pathways for these differences. Specifically, work has found that vitamin D insufficiency and hypovitaminosis D were common among Arab Americans and were linked to insulin resistance, metabolic syndrome and glucose intolerance in Arab American men (35). Researchers have also hypothesized that differences in disease burden may 
also be a result of lack of knowledge and care in this marginalized population.

A number of studies found a lack of appropriate diabetes education tools for Arab Americans $(36,37)$. Cultural and linguistic deficiencies in the existing educational literature may be preventing Arab Americans from fully understanding their risk for diabetes and their ability to improve their health. Cost and access to appropriate healthcare were barriers identified in a number of studies (38). Acculturation was found to influence diabetes control differently for men than for women. Negative associations between Arab acculturation and diabetes risk were found among Arab American men while American acculturation was found to be associated with diabetes risk among women (39). There were some religious barriers to diabetes control. Some woman cited concerns about modesty that prevented them from exercising properly (36). Ramadan poses a potential barrier to diabetes control in this population as well (40).

One of the first intervention studies implemented among Arab Americans was the adapted Diabetes Prevention Program (DPP) group lifestyle intervention $(41,42)$. The DPP was tailored linguistically and culturally to Arab American populations in the Dearborn Michigan area to encourage individuals to lose weight and understand their risk for diabetes. The program was successful, with individuals losing weight if they had family support and were appropriately educated on the benefits of the program. This intervention was one of the first successful implementations of intervention research in the Arab American community. The authors attribute their success to targeting gaps in knowledge and reducing misconceptions in recruiting and promoting participation. Arab Americans who perceived they were at increased risk of diabetes were more willing to participate in a lifestyle intervention than those who did not perceive they were at risk (43).

\section{Mental Health}

Research on mental health outcomes and the needs of Arab Americans with regard to mental health has increased since September 11th. While discrimination against Arab Americans is not new, discrimination, and stigmatization have increased in the United States over the past two decades $(1,44)$. Additionally, many Arab immigrants come to the United States from war torn and conflict-ridden regions increasing their exposure to traumatic and stressful experiences. Studies have documented higher incidence of psychological distress in the years following September 11th among Arab Americans (45). The overall prevalence of depression and other adverse mental health outcomes in Arab Americans is still relatively unknown. Recent studies among Arab American adolescents estimate that 14\% of Arab Americans living in the Dearborn ethnic enclave were diagnosed with depression (46), while another online study found that $50 \%$ of Arab-American respondents met criteria for depression (44). In particular, studies among Iraqi refugees suggested that this group was at particularly high risk for PTSD and overall health problems (47) and that a longer tenure in the United States was associated with increased depression for this population (48). The effort to estimate this psychological burden is deterred by a number of methodological challenges including the inability to easily identify Arab populations (49), the negative cultural attitudes toward counseling and psychotherapy (50-54), and the lack of targeted and culturally competent mental health services $(52,55)$ for Arab Americans.

Anti-Arab sentiment was associated with poor mental health outcomes including depression, distress, and unhappiness in Arab American populations $(45,56)$. Stress, specifically related to migration and the immigration experience, was examined among a group of Arab immigrant woman and found that postimmigration related stressors were correlated with depression and PTSD (57). In a study of Iraqi immigrants, pre-migration trauma was associated with higher rates of depression and PTSD (58). In one of a few randomized clinical trials reviewed, Iraqi refugees who had experienced post-traumatic stress were randomized to brief narrative exposure therapy or control (59). Investigators found that those who received brief narrative exposure therapy had greater posttraumatic growth and increased well-being alongside reduced symptomology for depression (59). Evidence suggests that there were challenges to psychotherapy for Arab Americans including hesitancy in discussing family problems outside of the family and a hesitancy to seek treatment. When individuals sought therapy, therapists reported a large amount of intergenerational conflicts and a difficulty to adjust to mainstream culture as primary complaints (50).

\section{Women's and Child Health}

The research in Arab American women's and child health is primarily focused on intimate partner violence, sexual health, obstetrics, and birth outcomes.

\section{Intimate partner violence}

Some studies found high prevalence of intimate partner violence in Arab American communities (60). Generally, Arab American woman exposed to intimate partner violence were at higher risk of depression (61). Woman who experienced intimate partner violence had many barriers to receiving care and support including language barriers, fear associated with discrimination, lack of culturally sensitive help, and a lack of trust of American providers $(60,62)$. There was mixed evidence for police intervention and the use of shelters for Arab American women (62). Some work has been done to understand the structural causes of intimate partner violence in Arab American populations including dependence on male relationships for stability and safety post immigration (62), patriarchal Arab culture, the lack of cultural support for seeking marital help outside of the family (61), and family honor, and blaming $(62,63)$. There is generally a critical need for domestic violence awareness and prevention programs in Arab American populations (64). Additionally, educating women about their rights and the care available to them may improve health seeking behavior alongside the increase in culturally competent health care providers for Arab American patients $(60,62,63)$.

\section{Female genital mutilation and sexual health}

The majority of the literature regarding the sexual health care needs of Arab American women focused on Somali women and 
those who experienced female genital mutilation. Female genital mutilation is the practice of partially or totally removing external genitalia of young girls and woman for nonmedical reasons (65). This practice is common in 30 countries in Africa, the Middle East and Asia (65). The prevalence and practice of female genital mutilation practices in the United States was low and rare $(66,67)$, but the number of those who come to the United States having experienced this in other countries was high (66). More research is needed in more diverse populations to understand the FGM practices in the United States and their impact on Arab American women's sexual health.

Knowledge and care for sexually transmitted diseases and HIV among Arab Americans was relatively low. While few research studies examined the sexual health needs of Arab American women, a study performed among Somali immigrants found low knowledge of STI/HIV risk factors, low condom use, and low incidence of extra-marital sex (66).

\section{Obstetrics}

All studies aiming to understand the obstetric needs of Arab Americans focused on Somali American populations. Among Somali refugees, women preferred little obstetric intervention (68) and clinicians who were more conservative with the use of C-sections $(69,70)$. Some authors noted that this was due to the fact that many women felt that in Somalia death after obstetric intervention was common (68) and many believed that there was a risk of not having future children after intervention (71). Prenatal education and programs helping mothers understand the options for obstetric care and reducing language barriers between patients and providers could reduce adverse obstetric outcomes (72-74).

\section{Birth}

Arab immigrants had lower odds of pre-term birth than U.S.born mothers (75). This trend is not unique to Arab Americans but to many immigrant groups (76). Some theorize that the reasons for this difference in pre-term birth includes the fact that immigrants who are able to immigrate to the United States are those that are healthy (77). Arab mothers tended to be healthier than non-Arab mothers with less tobacco use (78), less pregnancy-related hypertension and diabetes (79), lower rates of birth defects (80), and more consistent prenatal care (81). Somali women in particular faced poor obstetric outcomes due to poorer prenatal care (70) and feeling vulnerable and uninformed, but their outcomes improved with doula support (82). While there is great interest in whether or not adverse birth outcomes increased after September 11th, (83) did not find evidence of increased adverse birth outcomes after September 11th despite showing that stress and discrimination increase this risk among Arab mothers (84).

\section{Cancer}

Cancer rates among Arab American populations are relatively unknown, although the majority of work in this field has focused on breast cancer.

\section{Breast cancer}

Whether or not Arab Americans have a higher breast cancer associated mortality rate than non-Arab, non-Hispanic Whites is unclear. Evidence was found in both directions $(85,86)$. Arab American women tend to be diagnosed at a later stage of breast cancer and yet had higher overall survival than European and American women $(87,88)$. Barriers to breast cancer screening for Arab Americans included immigration-related barriers, fear, lack of knowledge, and access issues (89-94). Arab American women with higher levels of education and who have lived in the United States for long periods of time were more likely to get screened for breast cancer than their counterparts (95). Fatalism and religious beliefs have been cited by some authors as barriers to breast cancer screening (96). A recent study by Padela et al. found no correlation between fatalism and screening rates among Arab Americans (95).

\section{Other cancer}

Studies examining the perceptions of cancer among Arab Americans found that education, employment status, and the length of time one spends in the United States affected knowledge of cancer and screening (97). Many Arab Americans generally feared cancer (98) and some believed in keeping cancer diagnoses a secret in order to protect the image of the family in social settings (99). In one study of Arab American men and women, women were found to be more knowledgeable about the modifiable risk factors associated with cancer but that changing food habits was a point of concern (98). To improve perceptions and knowledge about cancer in Arab American populations, community educational programs targeting practices and knowledge within the Arab American community may help create change and awareness of risks (97, 99).

The barriers to screening and treatment of cancer among Arab Americans included lack of knowledge (100-103), religious and cultural beliefs about sickness $(100,104)$, fear and embarrassment (98, 103), language (101, 104), lack of culturally sensitive healthcare providers (100), lack of access to healthcare (105), and a need to maintain secrecy of sickness or disease (99). Community based participatory research was conducted among Arab Americans to address cancer education, prevention, and screening (106). This type of research was successful and found to increase cancer screening rates among an Arab American community in Detroit and can be used in future studies aiming to improve education and screening of other diseases.

Studies which include Arab Americans that aimed to estimate the incidence of particular cancers primarily focused on two comparisons: comparisons within Arab Americans (place of birth, gender, and country of origin) and comparing Arab American incidence to non-Hispanic, non-Arab White cancer incidence. Differences were observed in the incidence of cancer between foreign-born and U.S.-born Arab Americans and also between male and female Arab Americans (107). Differences of cancer incidence by country of origin were also found (108). Arab Americans, especially women, were at increased risk for thyroid cancer (107-110). Arab American men were found to be at increased risk of lung and prostate cancer when compared 
to Hispanic men, but had lower rates when compared to Black men (110). Manifestations of cancer also differed with Arab American men suffering from higher urinary incontinence associated with prostate cancer than White men (111). Arab American men had higher rates of bladder cancer than both Hispanic and black men (110). Risk factors for cancers differed between Arab American and non-Hispanic, non-Arab White women. White women tended to have a higher incidence of hormone, tobacco, and alcohol use while Arab American women had high vitamin $\mathrm{D}$ related deficiency and radiation exposure (109).

\section{Cardiovascular Disease}

There is a surprising lack of reliable and nationally representative data on cardiovascular disease among Arab Americans. Despite the fact that Arab Americans are generally cited to have higher cardiovascular disease risk than the general population, there is little evidence for this from the existing literature.

Prevalence of self-reported hypertension among Arab Americans (13.4\%) was found to be lower than prevalence among non-Hispanic Whites (24.5\%) in an analysis of the 2000-2003 National Health Interview Survey (33). A crosssectional descriptive study among Arab Americans in Southern California found a high prevalence of hypertension (36.5 and 39.7\% pre-hypertensive) (112).

A cross-sectional study among Arab Americans in Michigan found an overall prevalence of self-reported heart disease of 7.1\% and that Arab Americans were four times more likely to have heart disease than Black Americans in this sample (113). Studies of hypercholesterolemia found prevalence ranged from 24.6 to $44.8 \%$ among Arab Americans in various national and community-level convenience samples $(39,114)$. These numbers were well below the national average of $50.4 \%$ hypercholesterolemia in the United States population, but were not rigorously estimated using national and representative sampling methods (114).

Tailakh et al. attempted to understand the awareness of hypertension among a cross-sectional sample of Arab Americans in Southern California and determined that only $67.4 \%$ were aware of their hypertension and $52.2 \%$ were taking their antihypertensive medication (with $46 \%$ of those on medication having controlled blood pressure) (112). To our knowledge, no interventions have been tested to alter cardiovascular status among Arab Americans or influence the risk of developing cardiovascular disease in this population. This is in contrast to the numerous studies developing interventions to improve cardiovascular disease in the United States. While there is no mechanistic reason why interventions developed in other communities would not be transferrable to Arab Americans, it will be important to develop culturally relevant cardiovascular disease interventions for this population.

\section{Other Health Issues \\ Infectious disease}

The majority of research on infectious disease outcomes among Arab Americans focused on Somali immigrant populations in the Minnesota area $(115,116)$. More recent literature examined Hepatitis C among Somali immigrants in Minnesota and among Arabs in Southeast Michigan. Somali immigrants in Minnesota had high rates of hepatitis and hepatocellular carcinoma suggesting targeted interventions were needed for this population (117). The prevalence of Hepatitis $C$ virus antibodies among Arab Americans in Southeast Michigan was found to be triple the national average (5.4\%) suggesting the need for more studies assessing the burden of Hepatitis $\mathrm{C}$ in this community (118).

\section{Asthma}

Asthma prevalence has been found to vary by racial and ethnic groups in the United States (119). Evidence from recent studies shows that Arab Americans tended to have lower prevalence of asthma (9.4\%) than other racial and ethnic minorities including non-Hispanic Whites and Black Americans (14.4\%) (120). An important initiative, the Arab American Environmental Health Project (AAEHP) aimed to understand the impact of the environment on health among Arab Americans populations. One of the first studies published from this interdisciplinary project suggested that asthma prevalence was higher than previously reported among Arab Americans (16\%) but that asthma was more strongly correlated with environmental exposure among those with hypertension (121). Asthma management was also found to vary by English language fluency and acculturation variables, suggesting targeted interventions may need to be put in place to help those Arab Americans affected by asthma (122).

\section{Populations of Interest}

While many studies focused attention on the adult Arab American population in the United States, there are at-risk populations within this community that have been explicitly studied.

\section{Elderly}

Global demographics have shifted such that life expectancies are longer and many countries and populations are experiencing aging. The attention paid to the needs of elderly Arab Americans was minimal suggesting this as a future area of research. Better understanding the healthcare, social, and medical needs of the aging Arab American population in the United States is an important and urgent area of study. In our literature review, only three papers examined the needs of older Arab Americans. While Dallo et al. found a reduced likelihood of reporting a disability among Arab Americans when compared to other groups of color in the United States (123), Ajrouch synthesized information from a face-to-face survey and found that well-being varied with social capital for Arab American elders (124). More work is needed in this area to understand how to best care for aging Arab Americans and ensure their mental and physical well-being.

\section{Adolescents}

Adolescent Arab Americans are mostly composed of second generation Arab Americans, born in the United States to 
immigrant parents. In a large sample of Arab American adolescents, Ahmed et al. found that there was a strong relationship between perceived discrimination and poor mental health. Further, adolescents reporting more religious coping, strong ethnic identity, and religious support were found less likely to be psychologically distressed (125). An analysis by Aroian et al. (126) found that the quality of the motheradolescent relationship was the most important predictor of adolescent behavior and stress (127). Adolescents experienced a great deal of discrimination from teachers, school administrators, and their classmates suggesting the need for more dedicated research on how discrimination impacts adolescents (128). A recent analysis by Munro-Kramer et al. found two distinct subgroups of Arab American adolescents in their sample from the Midwest: those with multiple high risk behaviors and those with minimal risk behaviors and more positive life experiences (129). This analysis of high risk behaviors like sexual activity, tobacco use, and physical activity provides a perspective on the potential health needs of Arab American adolescents. The research on Arab American adolescents and their unique health risks requires further exploration and research.

\section{DISCUSSION}

In this updated comprehensive literature review of Arab American health, we found that the literature describing Arab American health outcomes and needs in the past decade has increased and expanded in geographic representation (Table 1). Publications discussing the health behaviors (especially physical activity, alcohol and drug use, and vaccination) of Arab Americans have increased in frequency since the publication of the literature review in 2009 alongside studies focusing on sexual health and female genital mutilation. Since the publication of the last review, a more substantial number of studies have examined the mental health needs of the Arab American population (44, 46, 48, 50, 51, 56, 195-202). Recent studies have improved upon the past literature by providing estimates of depression and depression symptoms among larger groups of Arab Americans alongside the examination of the risk factors (and resiliency factors) associated with this improved mental health but very few studies report on interventions to reduce mental health outcomes. Studies of cancer among Arab Americans have also increased in number since the last review, with a number of studies identifying incidence of a variety of cancers in Arab Americans (106-110) and another set of studies identifying barriers to screening, care and treatment in this population $(97-105,203)$. There have been more studies examining the risk of diabetes and cardiovascular disease in Arab Americans since 2009 (34-43, 112, 121, 141, 204-206), and more recent studies have examined successful targeted interventions to reduce risk factors for these diseases in ethnic enclaves (41-43). The implementation of intervention studies in Arab American populations is an improvement to the literature reported since the last review.

\section{Methodological Limitations in the Literature}

This review highlighted some methodological shortcomings of the existing literature on Arab American health that may prevent comparisons of health indicators to other ethnic groups in the United States. First is our inability to generalize findings from ethnic enclaves to areas where Arab Americans may be dispersed among other ethnic populations. The majority of studies aiming to understand health outcomes and health needs of Arab Americans took place within ethnic enclaves, primarily Dearborn Michigan, and Somali enclaves within Minnesota. In fact, regionally representative data sets using rigorous sampling methodologies (that have been invaluable for our understanding of Arab American health needs) have been overused and overpublished in the literature, suggesting that much of the information we have on Arab populations stems from a few datasets (ex. Detroit Arab American 2003 survey) within ethnic enclaves. While the identification and recruitment of Arab individuals in this area is made easier by social and cultural community connections, the lived experiences of these Arabs likely differs from those living in other parts of the country. Further, the large diversity of Arab populations residing in the United States with regard to country of origin, immigrant generation, and religion necessitates the study of diverse and nationally representative Arab samples in future studies.

Second, almost all studies were recruited through convenience sampling and very few studies used rigorous sampling methodologies to recruit samples of Arab Americans. This is in large part due to the absence of an easy way to identify Arab Americans on a wider scale and is a previously mentioned concern by other authors $(3,266)$. Investigators have used a variety of methods to isolate Arab Americans from larger datasets including Arab surname algorithms, using place of birth and Arabic language as indicators. Little is known about the generalizability of the findings from each of these methods.

Third, there were a general lack of prospective and longitudinal studies performed in this population- most studies were cross-sectional in nature. Longitudinal studies are able to follow individuals for longer periods of time to understand disease development. The longitudinal studies that were performed in this population have aimed to increase education, screening, or knowledge. Very few aim to alter disease status or examine interventions specific to disease reduction. The United States public health community has a long history of successful longitudinal studies aimed at understanding the burden of chronic diseases within particular populations (ex. Framingham Heart Study, Nurses' Health Study etc.) but the richness of these datasets cannot be used to understand Arab American health because, despite their likely presence in these datasets, Arab Americans cannot be isolated. These methodological challenges should be considered in the context of the future research directions recommended.

Unfortunately, many of the methodological shortcomings in the literature have persisted since the publication of the last review (3), suggesting the need for more active collaboration among researchers and institutions to overcome 
TABLE 1 | Characteristics of Arab American health studies identified through comprehensive review are summarized by number of studies identified and proportion of all studies identified.

\begin{tabular}{|c|c|c|c|}
\hline & $\begin{array}{l}\text { Number of studies } \\
\text { identified }(N=247)\end{array}$ & Proportion & References \\
\hline \multicolumn{4}{|l|}{ TIME PERIOD } \\
\hline 1980-1989 & 4 & $1.6 \%$ & $(130-133)$ \\
\hline 1990-1999 & 10 & $4.0 \%$ & $(11,64,69,134-140)$ \\
\hline 2000-2009 & 80 & $32.4 \%$ & $\begin{array}{l}(12,13,17,25,31-33,47,52,55,63,74,78,79,83,85,86,98,108,113-116 \\
122,124,127,141-194)\end{array}$ \\
\hline 2010-2017 & 153 & $61.9 \%$ & $\begin{array}{l}(14-16,18-24,29,30,34-46,48,50,51,53,54,56-62,66-68,70-73,75,80-82, \\
84,87-97,99-107,109-112,117,118,120,121,123,125,126,128,129,195-265)\end{array}$ \\
\hline \multicolumn{4}{|c|}{ COUNTRY OF ORIGIN OF SAMPLE (NOT EXCLUSIVE) } \\
\hline Egypt & 11 & $4.5 \%$ & $(54,55,79,135,146,151,152,185,186,240,245)$ \\
\hline Iraq & 39 & $15.8 \%$ & $\begin{array}{l}(11,31,47,48,54,58-61,79,93,94,99,109,124-126,143,151,152,171,172 \\
180,183-186,193-195,197,198,207,208,244,248,249,253,256)\end{array}$ \\
\hline Jordan & 8 & $3.2 \%$ & $(54,79,86,90,137,152,185,249)$ \\
\hline Kuwait & 3 & $1.2 \%$ & $(151,185,249)$ \\
\hline Lebanon & 28 & $11.3 \%$ & $\begin{array}{l}(11,31,36,54,55,61,79,99,102,109,124-126,143,151,152,180,183-186 \\
193,194,198,207,238,249,260)\end{array}$ \\
\hline Palestine & 15 & $6.1 \%$ & $(11,54,55,61,79,86,90,143,146,151,152,180,185,186,207)$ \\
\hline Saudi Arabia & 6 & $2.4 \%$ & $(54,79,146,151,152,249)$ \\
\hline Somalia & 66 & $26.7 \%$ & $\begin{array}{l}(15,21,22,30,34,51,53,54,66-74,82,89,94,100,101,103-105,115- \\
117,144,149,158,159,163,167,177,178,182,191,192,199,201,204,206, \\
209,210,212,214,218,219,222,224,226,227,230-233,235,237,241,243 \\
254,255,257,261,263)\end{array}$ \\
\hline Sudan & 9 & $3.6 \%$ & $(54,98,140,152,153,164,209,253,257)$ \\
\hline Syria & 11 & $4.5 \%$ & $(11,54,79,99,124,143,151,152,185,186,249)$ \\
\hline Yemen & 22 & $8.9 \%$ & $\begin{array}{l}(11,31,36,61,79,102,125,135,139,143,146,151,175,180,185,186,194 \\
198,207,238,249,260)\end{array}$ \\
\hline Mixed/Unspecified & 122 & $49.4 \%$ & $\begin{array}{l}(12-14,16-20,23,25,29,32,33,35,37-46,50,52,54-57,62- \\
64,75,78,80,81,83,84,87,88,91,92,95-97,106-108,110- \\
112,114,118,120-123,125,127-134,136,138,141,145,147,148,150,154- \\
157,162,165,166,168-170,173,174,176,181,187- \\
190,193,196,200,202,203,205,211,213,215-217,220,221,223,225,228, \\
229,234,236,239,242,246,247,251,252,258,259,262,264,265)\end{array}$ \\
\hline \multicolumn{4}{|c|}{ UNITED STATES LOCATION (NOT EXHAUSTIVE) } \\
\hline California & 11 & $4.5 \%$ & $(19,20,69,110,112,133,162,211,228,252,254)$ \\
\hline Washington D.C. & 2 & $0.8 \%$ & $(86,90)$ \\
\hline Illinois & 3 & $1.2 \%$ & $(95,264,265)$ \\
\hline Louisiana & 2 & $0.8 \%$ & $(39,81)$ \\
\hline Maine & 3 & $1.2 \%$ & $(73,212,226)$ \\
\hline Massachusetts & 4 & $1.6 \%$ & $(71,93,94,235)$ \\
\hline Michigan & 90 & $36.4 \%$ & $\begin{array}{l}(11-13,24,25,31,32,36-38,41-43,45-47,56-63,75,78,79,83- \\
85,87,92,97,99,102,106-111,113,118,120-122,124- \\
127,136,139,142,145,147,154,156,157,160,161,165,166,168,174,176,179- \\
181,183,184,187,190,193,194,196,197,202,207,208,217,220,221,223, \\
225,234,238,243,246,248,258)\end{array}$ \\
\hline Minnesota & 30 & $12.2 \%$ & $\begin{array}{l}(15,21,30,34,66,72,74,100,101,103-105,115-117,140,144,158,163,170 \\
178,192,201,210,218,222,224,237,257,263)\end{array}$ \\
\hline New Jersey & 2 & $0.8 \%$ & $(110,152)$ \\
\hline New York & 8 & $3.2 \%$ & $(52,68,152,167,185,213,215,245)$ \\
\hline Texas & 2 & $0.8 \%$ & $(14,229)$ \\
\hline Virginia & 4 & $1.6 \%$ & $(16,146,236,242)$ \\
\hline Washington & 3 & $1.2 \%$ & $(89,149,214)$ \\
\hline National & 8 & $3.2 \%$ & $(23,29,33,123,155,189,247,259)$ \\
\hline Multiple Cities & 9 & $3.6 \%$ & $(44,48,54,55,88,91,96,153,216)$ \\
\hline
\end{tabular}




\begin{tabular}{|c|c|c|c|}
\hline & $\begin{array}{l}\text { Number of studies } \\
\text { identified }(N=247)\end{array}$ & Proportion & References \\
\hline \multicolumn{4}{|c|}{ SAMPLING CHARACTERISTICS (NOT EXCLUSIVE) } \\
\hline $\begin{array}{l}\text { Convenience } \\
\text { sample }\end{array}$ & 171 & $69.2 \%$ & $\begin{array}{l}(12-14,16,17,20-22,25,36,37,39-42,46,50-55,57,59-64,67-74,81,82,85- \\
87,89-106,111-114,118,120,121,124-126,128-135,137,139-141,143- \\
146,148-154,157-159,164,167-173,175,177-186,188,190-195,197- \\
204,207,209-214,216,219,220,223,226-233,235,236,238-241,243,245, \\
248,249,251-257,260,262-265)\end{array}$ \\
\hline $\begin{array}{l}\text { Population based } \\
\text { sample }\end{array}$ & 69 & $27.9 \%$ & $\begin{array}{l}(11,12,15,23,29-35,38,43-45,47,48,56,58,75,78-80,83- \\
85,88,107,108,110,115-117,122,123,136,138,142,147,155,156,160- \\
163,165,166,174,176,180,187-189,196,205,206,208,215,218,221,222 \\
225,234,237,246,247,250,258,259)\end{array}$ \\
\hline Snowball sampling & 13 & $5.3 \%$ & $(22,54,91,127,135,167,177,199,203,232,235,244,261)$ \\
\hline $\begin{array}{l}\text { Web-based } \\
\text { sampling }\end{array}$ & 3 & $1.2 \%$ & $(54,55,177)$ \\
\hline \multicolumn{4}{|c|}{ STUDY CHARACTERISTICS (NOT EXCLUSIVE) } \\
\hline Cross-sectional & 196 & $79.4 \%$ & $\begin{array}{l}(11-25,32-40,43-46,48,50-57,60-64,66,71,72,74,81,82,86,89,91,93- \\
96,98-100,102,103,109-114,117,118,120-122,124,125,127- \\
161,163,164,166-195,197-202,204-211,213,214,216,217,219-221,223- \\
225,227-233,235,237-242,244-246,249,251-263,265)\end{array}$ \\
\hline Longitudinal & 30 & $12.2 \%$ & $\begin{array}{l}(29,30,42,59,75,78-80,83,84,88,92,105-108,115,116,123,126,162,165 \\
196,217,218,234,236,247,248,250)\end{array}$ \\
\hline Intervention & 15 & $6.1 \%$ & $(18,41,42,46,59,87,92,97,104,106,150,215,223,236,243)$ \\
\hline $\begin{array}{l}\text { Focus groups or } \\
\text { interviews }\end{array}$ & 77 & $31.2 \%$ & $\begin{array}{l}(19,21,24,36-38,51-53,62-64,66-71,73,74,81,82,89,90,93,94,96,98- \\
101,103,126,128-130,136,137,139,143,144,148,158,159,167,169,171 \\
178,185,191,192,195,199,201,207,210,212,214,215,219,224,227,229- \\
233,235,241,242,248,253,254,256,257,263,264)\end{array}$ \\
\hline
\end{tabular}

these limitations. These methodological shortcomings made a rigorous quality assessment of the literature difficult to conduct due to heterogeneity in the rigor of studies and the relatively recent nascence of the Arab American health literature. In the absence of a systematic quality assessment of the literature, our literature review could not be considered systematic, a limitation of our work.

While progress has been made in expanding the geographic representation of studies and the inclusion of a few randomized trials, more longitudinal studies with population-representative samples will help improve our understanding of Arab Americans.

\section{Future Research Directions}

Future studies should aim to understand the diverse healthcare needs of Arab Americans and to better understand how to improve their experiences in healthcare. All institutions and organizations with an interest in helping improve minority health should identify Arab American populations in their databases and provide culturally competent services for improved care. Information taken on intake forms should include expanded information on race, religion, and cultural practices that may inform the care or health decision making of minority populations. Community based participatory research can be used by these institutions to develop interventions and to understand the health needs and desires of Arab American populations alongside the cultural nuances that influence health.

Second, understanding the needs of vulnerable subpopulations within the Arab American community should be prioritized. Understanding health needs within elderly Arab populations and the impact that increased life expectancy will have on these populations is important to our understanding of Arab American health more generally. The cultural processes and traditions associated with elder care and medical care may influence the health needs and resources available to this vulnerable populations over time. Another vulnerable population in need of active study are adolescents, and particularly adolescent women. Due to the compounding issues of acculturation, stress, and puberty, the health behaviors of this population should be better understood to develop targeted interventions. Studies aiming to examine Arab American sexual health should expand beyond the realm of female genital mutilation and attempt to provide culturally competent care and culturally relevant solutions to sexual health issues in this population.

Third, increasing the amount of information collected about acculturation status including immigration generation is important and necessary. Understanding the factors that make Arab American and Arab immigrants resilient will help contextualize Arab American health in the minority health landscape in the United States. Collecting data on religion should become a regular part of studies on mental health among Arab Americans. Evidence shows that assimilated Muslim Arab Americans experience higher levels of discrimination compared to their less assimilated counterparts and assimilated Christian Arab Americans (54). A better understanding of the role of 
religion could lead to productive collaborations between mental health providers and faith based institutions.

Finally, more creative studies using natural, political, or environmental experiments will also help the medical community understand the needs of this population in relation to the changing social and political environment in the United States. Using novel data streams to more rigorously sample Arab Americans nationally will help the medical community understand the contexts in which Arab Americans are accessing healthcare and may help improve their social experience in the United States overall. Ensuring the security and confidentiality of Arab Americans in these studies should be prioritized and emphasized to continue increasing the confidence of this community with medical and public health research.

\section{Conclusion}

Arab Americans are a socially and politically important immigrant group in the United States that has been increasing in size due to increased immigration over the past decade. More attention is needed to better understand the social and health needs of this population in the context of the changing political climate. Public health and medical researchers can improve their understanding of the health needs of Arab Americans through the identification and active recruitment of Arab Americans, the focus on vulnerable sub-populations, collecting data on acculturation and religion, and using novel longitudinal data

\section{REFERENCES}

1. Arab American Institute Foundation. Underreported, Under Threat: Hate Crime in the United States and the Targeting of Arab Americans 1991-2016 (2018). Available online at: https://d3n8a8pro7vhmx.cloudfront.net/aai/ pages/14141/attachments/original/1532368901/EXECUTIVE_SUMMARY. pdf?1532368901 (Accessed July 30, 2018)

2. Jamal AA, Naber NC. Race and Arab Americans Before and After 9/11: From Invisible Citizens to Visible Subjects. Syracuse, NY: Syracuse University Press (2008).

3. El-Sayed AM, Galea S. The health of Arab-Americans living in the United States: a systematic review of the literature. BMC Public Health (2009) 9:272. doi: 10.1186/1471-2458-9-272

4. Arab American Demographics. Arab American Institute Foundation (2014). Available online at: http://www.aaiusa.org/demographics

5. Brittingham A, De la Cruz GP. We the People of Arab Ancestry in the United States. Washington, DC: US Census Bureau (2005).

6. Orfalea G. The Arab Americans: A History. Ithaca, NY: Interlink Books (2006).

7. Hassan SD. Arabs, race and the post-September 11 national security state. Middle East Rep. (2002) 32:16-21.

8. Executive Office of the President, Office of Management and Budget (OMB), Office of Information and Regulatory Affairs. Standard for the Classification of Federal Data on Race and Ethnicity (1995). Available online at: https://www. whitehouse.gov/omb/fedreg_race-ethnicity

9. Karoub J. Census Bureau may count Arab-Americans for the first time in 2020 (2015). Available online at: http://www.pbs.org/newshour/rundown/ census-bureau-considering-new-category-arab-americans-2020-count/

10. Moher D, Shamseer L, Clarke M, Ghersi D, Liberati A, Petticrew $\mathrm{M}$, et al. Preferred reporting items for systematic review and metaanalysis protocols (PRISMA-P) 2015 statement. Syst Rev. (2015) 4:1. doi: 10.1186/2046-4053-4-1

11. Rice VH, Kulwicki A. Cigarette use among Arab Americans in the Detroit metropolitan area. Public Health Rep. (1992) 107:589-94. streams. Understanding Arab American health needs in the context of the existing racial and minority health landscape in the United States will be important to better understanding immigrant health in the United States.

\section{AUTHOR CONTRIBUTIONS}

NA, AE-S, and SG contributed to the design of the research. NA implemented the research and analyzed the results. $\mathrm{NA}$, AE-S, and SG contributed to the writing of the manuscript.

\section{ACKNOWLEDGMENTS}

We thank the undergraduate research fellows from the Boston College W. F. Connell School of Nursing who assisted in the sorting of abstracts and full texts and for their assistance in the preliminary analysis for this comprehensive review: Margaret Dauer, Amanda Dulla, Amy Lu, and Kimberly Bretta. We would also like to thank the reviewers for their helpful comments in shaping the manuscript.

\section{SUPPLEMENTARY MATERIAL}

The Supplementary Material for this article can be found online at: https://www.frontiersin.org/articles/10.3389/fpubh. 2018.00262/full\#supplementary-material

12. Kulwicki A, Smiley K, Devine S. Smoking behavior in pregnant Arab Americans. MCN Am J Matern Child Nurs. (2007) 32:363-7. doi: 10.1097/01.NMC.0000298132.62655.0d

13. Templin T, Rice VH, Gadelrab H, Weglicki L, Hammad A, Kulwicki A, et al. Trends in tobacco use among Arab/Arab-American adolescents: preliminary findings. Ethn Dis. (2005) 15(1 Suppl. 1):8.

14. Athamneh L, Sansgiry SS, Essien EJ, Abughosh S. Predictors of intention to quit waterpipe smoking: a survey of arab americans in houston, Texas. J Addict. (2015) 2015:575479. doi: 10.1155/2015/575479

15. Giuliani KKW, Mire O, Leinberger-Jabari A, Ehrlich LC, Stigler MH, Pryce DJ, et al. Cigarettes and the somali diaspora tobacco use among somali adults in Minnesota. Am J Prev Med. (2012) 43(5. Suppl. 3): S205-13. doi: 10.1016/j.amepre.2012.08.002

16. El-Shahawy O, Haddad L. Correlation between nicotine dependence and barriers to cessation between exclusive cigarette smokers and dual (water pipe) smokers among Arab Americans. Subst Abuse Rehabil. (2015) 6:25-32. doi: $10.2147 /$ SAR.S72360

17. Al-Omari H, Scheibmeir M. Arab Americans' acculturation and tobacco smoking. J Transcult Nurs. (2009) 20:227-33. doi: $10.1177 / 1043659608330353$

18. Rice VH, Weglicki LS, Templin T, Jamil H, Hammad A. Intervention effects on tobacco use in Arab and non-Arab American adolescents. Addict Behav. (2010) 35:46-8. doi: 10.1016/j.addbeh.2009.07.005

19. Kahan D. Arab American college students' physical activity and body composition: reconciling middle east-west differences using the socioecological model. Res Q Exerc Sport. (2011) 82:118-28. doi: 10.1080/02701367.2011.10599728

20. Aqtash S, Van Servellen G. Determinants of health-promoting lifestyle behaviors among arab immigrants from the region of the levant. Res Nurs Health. (2013) 36:466-77. doi: 10.1002/nur.21555

21. Mohamed AA, Hassan AM, Weis JA, Sia IG, Wieland ML. Physical activity among Somali men in Minnesota: barriers, facilitators, and recommendations. Am J Mens Health. (2014) 8:35-44. doi: $10.1177 / 1557988313489132$ 
22. Dharod JM, Croom JE, Sady CG. Food insecurity: its relationship to dietary intake and body weight among somali refugee women in the United States. $J$ Nutr Educ Behav. (2013) 45:47-53. doi: 10.1016/j.jneb.2012.03.006

23. Arfken C, Arnetz B, Fakhouri M, Ventimiglia M, Jamil H. Alcohol use among arab americans: what is the prevalence? J Immigr Minor Health (2011) 13:713-8. doi: 10.1007/s10903-011-9447-8

24. Arfken CL, Owens D, Said M. Binge drinking among arab/chaldeans: an exploratory study. J Ethn Subst Abuse (2012) 11:277-93. doi: $10.1080 / 15332640.2012 .735163$

25. Arfken CL, Berry A, Owens D. Pathways for Arab Americans to substance abuse treatment in southeastern Michigan. J Muslim Ment Health (2009) 4:31-46. doi: 10.1080/15564900902785457

26. Burger AE, Reither EN, Hofmann ET, Mamelund S-E. The influence of hispanic ethnicity and nativity status on $2009 \mathrm{H} 1 \mathrm{~N} 1$ pandemic vaccination uptake in the United States. J Immigr Minor Health (2017) 20:561-8. doi: 10.1007/s10903-017-0594-4

27. Fry CA, Silverman EP, Miller S. Addressing pneumococcal vaccine uptake disparities among african-american adults in the United States. Public Health Nurs. (2016) 33:277-82. doi: 10.1111/phn.12257

28. Galbraith KV, Lechuga J, Jenerette CM, Moore LAD, Palmer MH, Hamilton JB. Parental acceptance and uptake of the HPV vaccine among AfricanAmericans and Latinos in the United States: a literature review. Soc Sci Med. (2016) 159:116-26. doi: 10.1016/j.socscimed.2016.04.028

29. Dallo FJ, Kindratt TB. Disparities in vaccinations and cancer screening among USand Foreign-Born Arab and European American NonHispanic White Women. Womens Health Issues (2015) 25:56-62. doi: 10.1016/j.whi.2014.10.002

30. Pruitt CN, Reese CS, Grossardt BR, Shire AM, Creedon DJ. Completion of the human papillomavirus vaccination series lags in Somali adolescents. J Low Genit Tract Dis. (2013) 17:280-8. doi: 10.1097/LGT.0b013e31827 $59 \mathrm{a} 64$

31. Jaber LA, Brown MB, Hammad A, Howak SN, Zhu Q, Ghafoor A, et al. Epidemiology of diabetes among Arab Americans. Diabetes Care (2003) 26:308-13. doi: 10.2337/diacare.26.2.308

32. Jaber LA, Brown MB, Hammad A, Zhu Q, Herman WH. The prevalence of the metabolic syndrome among Arab Americans. Diabetes Care (2004) 27:234-8. doi: 10.2337/diacare.27.1.234

33. Dallo FJ, Borrell LN. Self-reported diabetes and hypertension among Arab Americans in the United States. Ethn Dis. (2006) 16:699-705. doi: 10.1093/aje/163.suppl_11.S185-b

34. Njeru JW, Tan EM, St Sauver J, Jacobson DJ, Agunwamba AA, Wilson $\mathrm{PM}$, et al. High rates of diabetes mellitus, pre-diabetes and obesity among somali immigrants and refugees in minnesota: a retrospective chart review. J Immigr Minor Health (2016) 18:1343-9. doi: 10.1007/s10903-0150280-3

35. Pinelli NR, Jaber LA, Brown MB, Herman WH, Pinelli NR, Jaber LA, et al. Serum 25-hydroxy vitamin $\mathrm{d}$ and insulin resistance, metabolic syndrome, and glucose intolerance among Arab Americans. Diabetes Care (2010) 33:1373-5. doi: 10.2337/dc09-2199

36. Bertran EA, Fritz H, Abbas M, Tarakji S, DiZazzo-Miller R, Pociask FD, et al. The impact of arab american culture on diabetes self-management education. Diabetes Educ. (2015) 41:748-54. doi: 10.1177/0145721715 607356

37. Fritz H, DiZazzo-Miller R, Bertran EA, Pociask FD, Tarakji S, Arnetz $\mathrm{J}$, et al. Diabetes self-management among Arab Americans: patient and provider perspectives. BMC Int Health Hum Rights (2016) 16:22. doi: 10.1186/s12914-016-0097-8

38. Bertran EA, Pinelli NR, Sills SJ, Jaber LA. The Arab American experience with diabetes: Perceptions, myths and implications for culturally-specific interventions. Prim Care Diabetes (2017) 11:13-9. doi: $10.1016 /$ j.pcd.2016.07.004

39. Al-Dahir S, Brakta F, Khalil A, Benrahla M. The impact of acculturation on diabetes risk among Arab Americans in Southeastern Louisiana. J Health Care Poor Underserved. (2013) 24:47-63. doi: 10.1353/hpu. 2013.0038

40. Pinelli NR, Jaber LA. Practices of Arab American patients with type 2 diabetes mellitus during ramadan. J Pharm Pract. (2011) 24:211-5. doi: $10.1177 / 0897190010367432$
41. Pinelli NR, Brown MB, Herman WH, Jaber LA. Family support is associated with success in achieving weight loss in a group lifestyle intervention for diabetes prevention in Arab Americans. Ethn Dis. (2011) 21:480-4.

42. Jaber LA, Pinelli NR, Brown MB, Funnell MM, Anderson R, Hammad A, et al. Feasibility of group lifestyle intervention for diabetes prevention in Arab Americans. Diabetes Res Clin Pract. (2011) 91:307-15. doi: 10.1016/j.diabres.2010.11.032

43. Pinelli NR, Herman WH, Brown MB, Jaber LA, Pinelli NR, Herman WH, et al. Perceived risk and the willingness to enroll in a diabetes prevention lifestyle intervention in Arab-Americans. Diabetes Res Clin Pract. (2010) 90:27. doi: 10.1016/j.diabres.2010.08.010

44. Amer MM, Hovey JD. Anxiety and depression in a post-September 11 sample of Arabs in the USA. Soc Psychiatry Psychiatr Epidemiol. (2012) 47:409-18. doi: 10.1007/s00127-011-0341-4

45. Padela AI, Heisler M. The association of perceived abuse and discrimination after September 11, 2001, with psychological distress, level of happiness, and health status among Arab Americans. Am J Public Health (2010) 100:284-91. doi: 10.2105/AJPH.2009.164954

46. Jaber RM, Farroukh M, Ismail M, Najda J, Sobh H, Hammad A, et al. Measuring depression and stigma towards depression and mental health treatment among adolescents in an Arab-American community. Int J Cult Ment Health (2015) 8:247-54. doi: 10.1080/17542863.2014.953188

47. Jamil H, Hakim-Larson J, Farrag M, Kafaji T, Duqum I, Jamil LH. A retrospective study of Arab American mental health clients: trauma and the Iraqi refugees. Am J Orthopsychiatry (2002) 72:355-61. doi: 10.1037/0002-9432.72.3.355

48. Taylor E, Yanni E, Pezzi C, Guterbock M, Rothney E, Harton E, et al. Physical and mental health status of iraqi refugees resettled in the United States. $J$ Immigr Minor Health (2014) 16:1130-7. doi: 10.1007/s10903-013-9893-6

49. Abuelezam NN, El-Sayed AM, Galea S. Arab American health in a racially charged US. Am J Prev Med. (2017) 52:810-2. doi: 10.1016/j.amepre.2017.02.021

50. Martin U. Psychotherapy with Arab Americans: an exploration of therapyseeking and termination behaviors. Int J Cult Ment Health (2014) 7:162-7. doi: 10.1080/17542863.2012.742121

51. Ellis BH, Lincoln AK, Charney ME, Ford-Paz R, Benson M, Strunin L. Mental health service utilization of somali adolescents: religion, community, and school as gateways to healing. Transcult Psychiatry (2010) 47:789-811. doi: $10.1177 / 1363461510379933$

52. Abu-Ras W, Abu-Bader SH. The impact of the September 11, 2001, attacks on the well-being of Arab Americans in New York City. J Muslim Ment Health (2008) 3:217-39. doi: 10.1080/15564900802487634

53. Ellis BH, MacDonald HZ, Klunk-Gillis J, Lincoln A, Strunin L, Cabral HJ. Discrimination and mental health among Somali refugee adolescents: the role of acculturation and gender. Am J Orthopsychiatry (2010) 80:564-75. doi: 10.1111/j.1939-0025.2010.01061.x

54. Awad GH. The impact of acculturation and religious identification on perceived discrimination for Arab/Middle Eastern Americans. Cultur Divers Ethnic Minor Psychol. (2010) 16:59-67. doi: 10.1037/a0016675

55. Amer MM, Hovey JD. Socio-demographic differences in acculturation and mental health for a sample of 2nd generation/early immigrant Arab Americans. J Immigr Minor Health (2007) 9:335-47. doi: 10.1007/s10903-007-9045-y

56. Abdulrahim S, James SA, Yamout R, Baker W. Discrimination and psychological distress: does Whiteness matter for Arab Americans? Soc Sci Med. (2012) 75:2116-23. doi: 10.1016/j.socscimed.2012.07.030

57. Norris AE, Aroian KJ, Nickerson DM. Premigration persecution, postmigration stressors and resources, and postmigration mental health: a study of severely traumatized U.S. Arab Immigrant Women. J Am Psychiatr Nurses Assoc. (2011) 17:283-93. doi: 10.1177/1078390311408900

58. Arnetz BB, Templin T, Saudi W, Jamil H, Arnetz BB, Templin $\mathrm{T}$, et al. Obstructive sleep apnea, posttraumatic stress disorder, and health in immigrants. Psychosom Med. (2012) 74:824-31. doi: 10.1097/PSY.0b013e31826bflec

59. Hijazi AM, Lumley MA, Ziadni MS, Haddad L, Rapport LJ, Arnetz BB. Brief narrative exposure therapy for posttraumatic stress in Iraqi refugees: a preliminary randomized clinical trial. J Trauma Stress (2014) 27:314-22. doi: $10.1002 /$ jts. 21922 
60. Barkho E, Fakhouri M, Arnetz JE. Intimate partner violence among Iraqi immigrant women in Metro Detroit: a pilot study. J Immigr Minor Health (2011) 13:725-31. doi: 10.1007/s10903-010-9399-4

61. Kulwicki A, Ballout S, Kilgore C, Hammad A, Dervartanian H. Intimate partner violence, depression, and barriers to service utilization in arab American Women. J Transcult Nurs. (2015) 26:24-30. doi: 10.1177/1043659614524000

62. Kulwicki A, Aswad B, Carmona T, Ballout S. Barriers in the utilization of domestic violence services among Arab immigrant women: perceptions of professionals, service providers \& community leaders. J Fam Violence (2010) 25:727-35. doi: 10.1007/s10896-010-9330-8

63. Abu-Ras W. Cultural beliefs and service utilization by battered Arab immigrant women. Violence Against Women (2007) 13:1002-28. doi: 10.1177/1077801207306019

64. Kulwicki AD, Miller J. Domestic violence in the Arab American population: transforming environmental conditions through community education. Issues Ment Health Nurs. (1999) 20:199-215.

65. Organization WH. Female Genital Mutilation, Fact Sheet (2018). Available online at: http://www.who.int/mediacentre/factsheets/fs241/en/

66. Connor JJ, Hunt S, Finsaas M, Ciesinski A, Ahmed A, Robinson BBE. Sexual health care, sexual behaviors and functioning, and female genital cutting: perspectives from somali women living in the United States. J Sex Res. (2016) 53:346-59. doi: 10.1080/00224499.2015.1008966

67. McNeely S, Christie-de Jong F. Somali refugees' perspectives regarding FGM/C in the US. Int J Migr Health Soc Care (2016) 12:157-69. doi: 10.1108/IJMHSC-09-2015-0033

68. Brown E, Carroll J, Fogarty C, Holt C. 'They get a C-section...they gonna die': Somali women's fears of obstetrical interventions in the United States. $J$ Transcult Nurs. (2010) 21:220-7. doi: 10.1177/1043659609358780

69. Beine K, Fullerton J, Palinkas L, Anders B. Conceptions of prenatal care among Somali women in San Diego. J Nurse Midwifery (1995) 40:376-81. doi: 10.1016/0091-2182(95)00024-E

70. Johnson-Agbakwu CE, Helm T, Killawi A, Padela AI. Perceptions of obstetrical interventions and female genital cutting: insights of men in a Somali refugee community. Ethn Health (2014) 19:440-57. doi: 10.1080/13557858.2013.828829

71. Ameresekere M, Borg R, Frederick J, Vragovic O, Saia K, Raj A. Somali immigrant women's perceptions of cesarean delivery and patient-provider communication surrounding female circumcision and childbirth in the USA. Int J Gynaecol Obstet. (2011) 115:227-30. doi: 10.1016/j.ijgo.2011.07.019

72. DeStephano CC, Flynn PM, Brost BC. Somali prenatal education video use in a United States obstetric clinic: a formative evaluation of acceptability. Patient Educ Couns. (2010) 81:137-41. doi: 10.1016/j.pec.2009.12.003

73. Jacoby SD, Lucarelli M, Musse F, Krishnamurthy A, Salyers V. A mixedmethods study of immigrant somali women's health literacy and perinatal experiences in maine. J Midwifery Womens Health (2015) 60:593-603. doi: 10.1111/jmwh.12332

74. Herrel N, Olevitch L, DuBois DK, Terry P, Thorp D, Kind E, et al. Somali refugee women speak out about their needs for care during pregnancy and delivery. J Midwifery Womens Health (2004) 49:345-9. doi: 10.1016/j.jmwh.2004.02.008

75. El-Sayed A, Galea S. Interethnic mating and risk for preterm birth among Arab-American mothers: Evidence from the Arab-American Birth Outcomes Study. J Immigr Minor Health (2011) 13:445-52. doi: 10.1007/s10903-010-9341-9

76. Singh GK, Yu SM. Adverse pregnancy outcomes: differences between USand foreign-born women in major US racial and ethnic groups. Am J Public Health (1996) 86:837-43.

77. Wingate MS, Alexander GR. The healthy migrant theory: variations in pregnancy outcomes among US-born migrants. Soc Sci Med. (2006) 62:4918. doi: 10.1016/j.socscimed.2005.06.015

78. El-Sayed AM, Galea S. Explaining the low risk of preterm birth among Arab Americans in the United States: an analysis of 617451 births. Pediatrics (2009) 123:438. doi: 10.1542/peds.2008-1634

79. El Reda DK, Grigorescu V, Posner SF, Davis-Harrier A. Lower rates of preterm birth in women of Arab ancestry: an epidemiologic paradox-Michigan, 1993-2002. Matern Child Health J. (2007) 11:622-7. doi: 10.1007/s10995-007-0199-y
80. Yanni EA, Copeland G, Olney RS. Birth defects and genetic disorders among Arab Americans - Michigan, 1992-2003. J Immigr Minor Health (2010) 12:408-13. doi: 10.1007/s10903-008-9203-x

81. Ma P, Magnus M, Magnus J. Perception of pregnancy related health issues among arab women living in the United States. J Immigr Minor Health (2013) 15:273-80. doi: 10.1007/s10903-012-9589-3

82. Wojnar DM. Perinatal experiences of somali couples in the United States. J Obstet Gynecol Neonatal Nurs. (2015) 44:358-69. doi: 10.1111/1552-6909.12574

83. El-Sayed A, Hadley C, Galea S. Birth outcomes among Arab Americans in Michigan before and after the terrorist attacks of September 11, 2001. Ethn Dis. (2008) 18:348-56.

84. El-Sayed AM, Galea S. Community context, acculturation and low-birthweight risk among Arab Americans: evidence from the Arab-American birth-outcomes study. J Epidemiol Community Health (2010) 64:155-60. doi: 10.1136/jech.2008.084491

85. Hensley Alford S, Schwartz K, Soliman A, Johnson CC, Gruber SB, Merajver SD. Breast cancer characteristics at diagnosis and survival among ArabAmerican women compared to European- and African-American women. Breast Cancer Res Treat. (2009) 114:339-46. doi: 10.1007/s10549-0089999-z

86. Kawar LN. Jordanian and palestinian immigrant women's knowledge, affect, cultural attitudes, health habits, and participation in breast cancer screening. Health Care Women Int. (2009) 30:768-82. doi: 10.1080/073993309030 66111

87. Arshad S, Williams KP, Mabiso A, Dey S, Soliman AS. Evaluating the knowledge of breast cancer screening and prevention among Arab-American women in Michigan. J Cancer Educ. (2011) 26:135-8. doi: 10.1007/s13187-010-0130-x

88. Hirko KA, Soliman AS, Banerjee M, Ruterbusch J, Harford JB, Chamberlain $\mathrm{RM}$, et al. Characterizing inflammatory breast cancer among Arab Americans in the California, Detroit and New Jersey Surveillance, Epidemiology and End Results (SEER) registries (1988-2008). Springerplus (2013) 2:3. doi: 10.1186/2193-1801-2-3

89. Al-Amoudi S, Cañas J, Hohl SD, Distelhorst SR, Thompson B. Breaking the silence: breast cancer knowledge and beliefs among somali muslim women in seattle, Washington. Health Care Women Int. (2015) 36:608-16. doi: 10.1080/07399332.2013.857323

90. Kawar LN. Barriers to breast cancer screening participation among Jordanian and Palestinian American women. Eur J Oncol Nurs. (2013) 17:88-94. doi: 10.1016/j.ejon.2012.02.004

91. Petro-Nustas W, Norton ME, Vilhauer RP, Connelly AD. Health beliefs associated with breast cancer screening among Arab women in the Northeastern United States. Int J Health Promot Educ. (2012) 50:273-7. doi: 10.1080/14635240.2012.723374

92. Williams KP, Mabiso A, Todem D, Hammad A, Hill-Ashford Y, Hamade H, et al. Differences in knowledge of breast cancer screening among African American, Arab American, and Latina women. Prev Chronic Dis. (2011) 8:A20. Available online at: www.cdc.gov/pcd/issues/2011/jan/09_0185.htm (Accessed on August 30, 2018).

93. Saadi A, Bond B, Percac-Lima S. Perspectives on preventive health care and barriers to breast cancer screening among iraqi women refugees. J Immigr Minor Health (2012) 14:633-9. doi: 10.1007/s10903-0119520-3

94. Saadi A, Bond BE, Percac-Lima S. Bosnian, iraqi, and somali refugee women speak: a comparative qualitative study of refugee health beliefs on preventive health and breast cancer screening. Women's Health Issues (2015) 25:501-8. doi: 10.1016/j.whi.2015.06.005

95. Padela A, Murrar S, Adviento B, Liao C, Hosseinian Z, Peek M, et al. Associations between religion-related factors and breast cancer screening among american muslims. J Immigr Minor Health (2015) 17:660-9. doi: 10.1007/s10903-014-0014-y

96. Obeidat RF, Lally RM, Dickerson SS. Arab american women's lived experience with early-stage breast cancer diagnosis and surgical treatment. Cancer Nurs. (2012) 35:302-11. doi: 10.1097/NCC.0b013e318231db09

97. Dallo FJ, Zakar T, Borrell LN, Fakhouri M, Jamil H. Cancer knowledge increases after a brief intervention among Arab Americans in Michigan. $J$ Cancer Educ. (2011) 26:139-46. doi: 10.1007/s13187-010-0179-6 
98. Elmubarak E, Bromfield E, Bovell-Benjamin AC, Elmubarak E, Bromfield E, Bovell-Benjamin A. Focused interviews with Sudanese Americans: perceptions about diet, nutrition, and cancer. Prev Med. (2005) 40:502-9. doi: 10.1016/j.ypmed.2004.09.021

99. Mellon S, Gauthier J, Cichon M, Hammad A, Simon M. Knowledge, Attitudes, and Beliefs of Arab-American Women Regarding Inherited Cancer Risk. J Genet Couns. (2013) 22:268-76. doi: 10.1007/s10897-012-9546-2

100. Ghebre R, Sewali B, Osman S, Adawe A, Nguyen H, Okuyemi K, et al. Cervical cancer: barriers to screening in the somali community in minnesota. J Immigr Minor Health (2015) 17:722-8. doi: 10.1007/s10903-014-0080-1

101. Sewali B, Pratt R, Abdiwahab E, Fahia S, Call KT, Okuyemi KS. Understanding cancer screening service utilization by somali men in Minnesota. J Immigr Minor Health (2015) 17:773-80. doi: 10.1007/s10903-014-0032-9

102. Talaat N. Adherence and barriers to colorectal cancer screening varies among Arab Americans from different countries of origin. Arab J Gastroenterol. (2015) 16:116-20. doi: 10.1016/j.ajg.2015.07.003

103. Raymond NC, Osman W, O’Brien JM, Ali N, Kia F, Mohamed F, et al. Culturally informed views on cancer screening: a qualitative research study of the differences between older and younger Somali immigrant women. BMC Public Health (2014) 14:1-16. doi: 10.1186/1471-2458-14-1188

104. Sewali B, Okuyemi KS, Askhir A, Belinson J, Vogel RI, Joseph A, et al. Cervical cancer screening with clinic-based Pap test versus home HPV test among Somali immigrant women in Minnesota: a pilot randomized controlled trial. Cancer Med. (2015) 4:620-31. doi: 10.1002/ cam 4.429

105. Morrison TB, Flynn PM, Weaver AL, Wieland ML. Cervical cancer screening adherence among somali immigrants and refugees to the United States. Health Care Women Int. (2013) 34:980-8. doi: 10.1080/07399332.2013.770002

106. Vicini FA, Shah C, Wallace M, Jones P, Dykes V, Tull J, et al. Strategies for reducing cancer incidence and mortality in African American and Arab American and Chaldean communities in the Detroit metropolitan area. Am J Clin Oncol. (2012) 35:316-21. doi: 10.1097/COC.0b013e31821 0f9b5

107. Khan F, Ruterbusch JJ, Gomez SL, Schwartz K. Differences in the cancer burden among foreign-born and US-born Arab Americans living in metropolitan Detroit. Cancer Causes Control. (2013) 24:1955-61. doi: 10.1007/s10552-013-0271-4

108. Schwartz KL, Kulwicki A, Weiss LK, Fakhouri H, Sakr W, Kau G, et al. Cancer among Arab Americans in the metropolitan Detroit area. Ethn Dis. (2004) 14:141-6.

109. Peterson L, Soliman A, Ruterbusch J, Smith N, Schwartz K. Comparison of exposures among arab american and non-hispanic white female thyroid cancer cases in metropolitan detroit. $J$ Immigr Minor Health (2011) 13:1033-40. doi: 10.1007/s10903-0119485-2

110. Bergmans R, Soliman AS, Ruterbusch J, Meza R, Hirko K, Graff J, et al. Cancer incidence among arab americans in california, detroit, and new jersey SEER registries. Am J Public Health (2014) 104:83. doi: 10.2105/AJPH.2014.301954

111. Moussawi A, Yassine M, Dey S, Soliman A. Clinical profile, quality of care, and recurrence in arab-american and caucasians prostate cancer patients in michigan. J Immigr Minor Health (2013) 15:803-9. doi: 10.1007/s10903-012-9662-y

112. Tailakh A, Mentes JC, Morisky DE, Pike NA, Phillips LR, Evangelista LS. Prevalence, awareness, treatment, and control of hypertension among arab Americans. J Cardiovasc Nurs. (2013) 28:330-7. doi: 10.1097/JCN.0b013e31825638ae

113. Jamil H, Fakhouri M, Dallo F, Templin T, Khoury R, Fakhouri H. Selfreported heart disease among Arab and Chaldean American women residing in southeast Michigan. Ethn Dis. (2008) 18:19-25.

114. Jamil H, Templin T, Fakhouri M, Rice VH, Khouri R, Fakhouri H. Comparison of personal characteristics, tobacco use, and health states in Chaldean, Arab American, and non-Middle Eastern white adults. J Immigr Minor Health (2009) 11:310-7. doi: 10.1007/s10903-0089125-7
115. Kempainen R, Nelson K, Williams DN, Hedemark L. Mycobacterium tuberculosis disease in Somali immigrants in Minnesota. Clinical Investigations (2001) 119:176-80. doi: 10.1378/chest.119.1.176

116. Rock RB, Sutherland WM, Baker C, Williams DN. Extrapulmonary tuberculosis among Somalis in Minnesota. Emerg Infect Dis. (2006) 12:14346. doi: 10.3201/eid1209.050295

117. Shire AM, Sandhu DS, Kaiya JK, Oseini AM, Yang JD, Chaiteerakij R, et al. Viral hepatitis among somali immigrants in minnesota: association of hepatitis C with hepatocellular carcinoma. Mayo Clin Proc. (2012) 87:17-24. doi: 10.1016/j.mayocp.2011.08.001

118. Jamil LH, Duffy MC, Fakhouri M, Jamil HJ. Prevalence of antibodies to the hepatitis $\mathrm{C}$ virus among arab and chaldean Americans in Southeast Michigan, Usa. Ethn Dis. (2013) 23:18-21.

119. Gold DR, Wright R. Population disparities in asthma. Annu Rev Public Health (2005) 26:89-113. doi: 10.1146/annurev.publhealth.26.021304.144528

120. Jamil H, Raymond D, Fakhouri M, Templin T, Khoury R, Fakhouri H, et al. Self-reported asthma in chaldeans, arabs, and african Americans: factors associated with asthma. J Immigr Minor Health (2011) 13:568-75. doi: 10.1007/s10903-010-9390-0

121. Johnson M, Nriagu J, Hammad A, Savoie K, Jamil H. Asthma, environmental risk factors, and hypertension among arab Americans in metro detroit. J Immigr Minor Health (2010) 12:640-51. doi: 10.1007/s10903-008-9205-8

122. Johnson M, Nriagu J, Hammad A, Savoie K, Jamil H. Asthma prevalence and severity in Arab American communities in the Detroit area, Michigan. J Immigr Health (2005) 7:165-78. doi: 10.1007/s10903-005-3673-x

123. Dallo F, Booza J, Nguyen N. Functional limitations and nativity status among Older Arab, Asian, Black, Hispanic, and White Americans. J Immigr Minor Health (2015) 17:535-42. doi: 10.1007/s10903-013-9943-0

124. Ajrouch KJ. Resources and well-being among Arab-American elders. J Cross Cult Gerontol. (2007) 22:167-82. doi: 10.1007/s10823-006-9033-z

125. Ahmed SR, Kia-Keating M, Tsai KH. A structural model of racial discrimination, acculturative stress, and cultural resources among Arab American adolescents. Am J Community Psychol. (2011) 48:181-92. doi: 10.1007/s10464-011-9424-3

126. Aroian KJ, Templin TN, Hough EE, Ramaswamy V, Katz A. A longitudinal family-level model of Arab Muslim adolescent behavior problems. J Youth Adolesc. (2011) 40:996-1011. doi: 10.1007/s10964-010-9615-5

127. Aroian K, Hough ES, Templin TN, Kulwicki A, Ramaswamy V, Katz A. A model of mother-child adjustment in Arab Muslim immigrants to the US. Soc Sci Med. (2009) 69:1377-86. doi: 10.1016/j.socscimed.2009.08.027

128. Aroian KJ. Discrimination against muslim american adolescents. J Sch Nurs. (2012) 28:206-13. doi: 10.1177/1059840511432316

129. Munro-Kramer M, Fava NM, Saftner MA, Darling-Fisher C, Tate NH, Stoddard SA, et al. What are we missing? Risk behaviors among ArabAmerican adolescents and emerging adults. J Am Assoc Nurse Pract. (2016) 28:493-502. doi: 10.1002/2327-6924.12352

130. Abu-Saad H. Cultural components of pain: the Arab-American child. Issues Compr Pediatr Nurs. (1984) 7:91-9. doi: 10.3109/01460868409009047

131. Lipson JG, Reizian AE, Meleis AI. Arab-American patients: a medical record review. Soc Sci Med. (1987) 24:101-7. doi: 10.1016/0277-9536(87)90242-5

132. Reizian A, Meleis AI. Symptoms reported by Arab-American patients on the Cornell Medical Index (CMI). West J Nurs Res. (1987) 9:368-84. doi: 10.1177/019394598700900308

133. Laffrey SC, Meleis AI, Lipson JG, Solomon M, Omidian PA. Assessing Arab-American health care needs. Soc Sci Med. (1989) 29:877-83. doi: 10.1016/0277-9536(89)90087-7

134. May KM. Middle-Eastern immigrant parents' social networks and helpseeking for child health care. J Adv Nurs. (1992) 17:905-12.

135. Meleis AI, Lipson JG, Paul SM. Ethnicity and health among five Middle Eastern immigrant groups. Nurs Res. (1992) 41:98-103. doi: 10.1097/00006199-199203000-00008

136. Kulwicki A, Cass PS. An assessment of Arab American knowledge, attitudes, and beliefs about AIDS. Image J Nurs Sch. (1994) 26:13-7. doi: 10.1111/j.1547-5069.1994.tb00288.x

137. Hattarpollara M, Meleis AI. The stress of immigration and the daily lived experiences of jordanian immigrant women in the United-States. West J Nurs Res. (1995) 17:521-39. doi: 10.1177/019394599501700505 
138. Jaber LA, Slaughter RL, Grunberger G. Diabetes and related metabolic risk-factors among arab-americans. Ann Pharmacother. (1995) 29:573-6. doi: 10.1177/106002809502900603

139. Kulwicki A. An ethnographic study of illness perceptions and practices of Yemeni-Arabs in Michigan. J Cult Divers. (1996) 3:80-9.

140. Power DV, Shandy DJ. Sudanese refugees in a Minnesota family practice clinic. Fam Med. (1998) 30:185-9.

141. Chatkoff DK, Leonard MT. A preliminary investigation of cognitive appraisal and cardiovascular reactivity and recovery in Arab Americans. Ethn Dis. (2009) 19:258-64.

142. Dallo FJ, James SA. Acculturation and blood pressure in a community-based sample of Chaldean-American women. J Immigr Health. (2000) 2:145-53. doi: 10.1023/A:1009560903668

143. Kulwicki AD, Miller J, Schim SM. Collaborative partnership for culture care: enhancing health services for the Arab community. J Transcult Nurs. (2000) 11:31-9. doi: 10.1177/104365960001100106

144. Greeson CJ, Veach PM, LeRoy BS. A Qualitative investigation of somali immigrant perceptions of disability: implications for genetic counseling. $J$ Genet Couns. (2001) 10:359-78. doi: 10.1023/A:1016625103697

145. Hatahet W, Khosla P, Fungwe TV. Prevalence of risk factors to coronary heart disease in an Arab-American population in southeast Michigan. Int J Food Sci Nutr. (2002) 53:325-35. doi: 10.1080/09637480220138124

146. Islam SMS, Johnson CA. Correlates of smoking behavior among Muslim Arab-American adolescents. Ethn Health. (2003) 8:319-37. doi: 10.1080/13557850310001631722

147. Jaber LA, Brown MB, Hammad A, Zhu Q, Herman WH. Lack of acculturation is a risk factor for diabetes in Arab immigrants in the U.S. Diabetes Care (2003) 26:2010-4. doi: 10.2337/diacare.26.7.2010

148. Kulwicki A, Rice VH. Arab American adolescent perceptions and experiences with smoking. Public Health Nurs. (2003) 20:177-83. doi: 10.1046/j.0737-1209.2003.20304.x

149. Read RW, Chen PP, Bhandari A, Mills RP, Cinciripini GS, Taylor CC. Intraocular pressure in a Somali population living in the United States. $J$ Glaucoma (2003) 12:365-9. doi: 10.1097/00061198-200308000-00012

150. Rice VH, Templin $\mathrm{T}$, Kulwicki A. Arab-American adolescent tobacco use: four pilot studies. Prev Med. (2003) 37:492-8. doi: 10.1016/S0091-7435(03)00175-0

151. Barry DT. Measuring acculturation among male Arab immigrants in the United States: an exploratory study. J Immigr Health (2005) 7:179-84. doi: 10.1007/s10903-005-3674-9

152. Beitin BK, Allen KR. Resilience in Arab American couples after September 11, 2001: a systems perspective. J Marital Fam Ther. (2005) 31:251-67. doi: 10.1111/j.1752-0606.2005.tb01567.x

153. Geltman PL, Grant-Knight W, Mehta SD, Lloyd-Travaglini C, Lustig S, Landgraf JM, et al. The 'lost boys of Sudan': functional and behavioral health of unaccompanied refugee minors resettled in the United States. Arch Pediatr Adolesc Med. (2005) 159:585-91. doi: 10.1001/archpedi.159.6.585

154. Johnson M, Hammad A, Nriagu JO, Savoie K, Jamil H. Environmental disease burden in Arab-American communities in the Detroit area: prevalence and severity. Ethn Dis. (2005) 15(1 Suppl. 1):6.

155. Read JnG, Amick B, Donato KM. Arab immigrants: a new case for ethnicity and health? Soc Sci Med. (2005) 61:77-82. doi: 10.1016/j.socscimed.2004.11.054

156. Slotnick MJ, Nriagu JO, Johnson MM, Linder AM, Savoie KL, Jamil $\mathrm{HJ}$, et al. Profiles of trace elements in toenails of Arab-Americans in the Detroit area, Michigan. Biol Trace Elem Res. (2005) 107:113-26. doi: 10.1385/BTER:107:2:113

157. Rice, V. H., Weglicki, L. S., Templin, T., Hammad, A., Jamil, H., and Kulwicki, A. Predictors of Arab American adolescent tobacco use. Merrill Palmer Q. (Wayne State Univ. Press) (2006). 52:327-42.

158. Wissink L, Jones-Webb R, DuBois D, Krinke B, Ibrahim Q. Improving health care provision to Somali refugee women. Minn Med. (2005) 88:36-40.

159. DeShaw PJ. Use of the emergency department by Somali immigrants and refugees. Minn Med. (2006) 89:42-5.

160. Kridli SA-O, Herman WH, Brown MB, Fakhouri H, Jaber LA. The epidemiology of diabetes and its risk factors among Chaldean Americans. Ethn Dis. (2006) 16:351-6.
161. Kridli SA-O, Herman WH, Brown MB, Fakhouri H, Jaber LA. For the patient. Diabetes and its risk factors among Chaldean Americans. Ethn Dis. (2006) $16: 588$.

162. Lauderdale DS. Birth outcomes for Arabic-named women in California before and after September 11. Demography (2006) 43:185-201. doi: 10.1353/dem.2006.0008

163. Robertson CL, Halcon L, Savik K, Johnson D, Spring M, Butcher J, et al Somali and Oromo refugee women: trauma and associated factors. $J A d v$ Nurs. (2006) 56:577-87. doi: 10.1111/j.1365-2648.2006.04057.x

164. Tompkins M, Smith L, Jones K, Swindells S. HIV education needs among Sudanese immigrants and refugees in the Midwestern United States. AIDS Behav. (2006) 10:319-23. doi: 10.1007/s10461-0059060-8

165. Wei S, Feldman GL, Monaghan KG. Cystic fibrosis testing among Arab-Americans. Genet Med. (2006) 8:255-8. doi: 10.1097/01.gim.0000214453.74456.f3

166. Berlie HD, Hammad A, Jaber LA. The use of glucose-lowering agents and aspirin among Arab Americans with diabetes. Ethn Dis. (2007) 17(2, Suppl. 3):S45.

167. Carroll J, Epstein R, Fiscella K, Volpe E, Diaz K, Omar S. Knowledge and beliefs about health promotion and preventive health care among Somali women in the United States. Health Care Women Int. (2007) 28:360-80. doi: 10.1080/07399330601179935

168. El-Essawi D, Musial JL, Hammad A, Lim HW. A survey of skin disease and skin-related issues in Arab Americans. J Am Acad Dermatol. (2007) 56:933-8. doi: 10.1016/j.jaad.2007.01.031

169. Hassouneh DM, Kulwicki A. Mental health, discrimination, and trauma in Arab Muslim women living in the US: a pilot study. Ment Health Relig Cult. (2007) 10:257-62. doi: 10.1080/13694670600630556

170. Hu WT, Foley TA, Wilcox RA, Kozera RM, Morgenstern BZ, Juhn YJ. Childhood obesity among Head Start enrollees in southeastern Minnesota: Prevalence and risk factors. Ethn Dis. (2007) 17:23-8.

171. Jamil H, Farrag M, Hakim-Larson J, Kafaji T, Abdulkhaleq H, Hammad A. Mental health symptoms in Iraqi refugees: posttraumatic stress disorder, anxiety, and depression. J Cult Divers. (2007) 14:19-25.

172. Jamil H, Nassar-McMillan SC, Lambert RG. Immigration and attendant psychological sequelae: a comparison of three waves of Iraqi immigrants. Am J Orthopsychiatry (2007) 77:199-205. doi: 10.1037/0002-9432.77.2.199

173. Weglicki LS, Templin T, Hammad A, Jamil H, Abou-Mediene S, Farroukh M, et al. Tobacco use patterns among high school students: do Arab American youth differ? Ethn Dis. (2007) 17(2, Suppl. 3):S24.

174. Arfken CL, Kubiak SP, Farrag M. Arab Americans in publicly financed alcohol/other drug abuse treatment. Alcohol Treat Q. (2008) 26:229-40. doi: 10.1080/07347320802071547

175. Baker OG, Rice V. Predictors of narghile (water-pipe) smoking in a sample of American Arab Yemeni adolescents. J Transcult Nurs. (2008) 19:24-32. doi: 10.1177/1043659607309141

176. Berlie HD, Herman WH, Brown MB, Hammad A, Jaber LA. Quality of diabetes care in Arab Americans. Diabetes Res Clin Pract. (2008) 79:249-55. doi: 10.1016/j.diabres.2007.09.003

177. Ellis BH, MacDonald HZ, Lincoln AK, Cabral HJ. Mental health of Somali adolescent refugees: the role of trauma, stress, and perceived discrimination. J Consult Clin Psychol. (2008) 76:184-93. doi: 10.1037/0022-006X. 76.2.184

178. Giuliani KKW, Mire OA, Jama S, DuBois DK, Pryce D, Fahia S, et al. Tobacco use and cessation among somalis in minnesota. Am J Prev Med. (2008) 35(6, Suppl. S):S462. doi: 10.1016/j.amepre.2008.09.006

179. Jamil H, Fakhouri M, Dallo F, Templin T, Khoury R, Fakhouri H. Disparities in self-reported diabetes mellitus among Arab, Chaldean, and Black Americans in Southeast Michigan. J Immigr Minor Health. (2008) 10:397-405. doi: 10.1007/s10903-007-9108-0

180. Jamil H, Grzybowski M, Hakim-Larson J, Fakhouri M, Sahutoglu J, Khoury $\mathrm{R}$, et al. Factors associated with self-reported depression in Arab, Chaldean, and African Americans. Ethn Dis. (2008) 18:464-70.

181. Kulwicki A, Khalifa R, Moore G. The effects of September 11 on Arab American nurses in metropolitan Detroit. J Transcult Nurs. (2008) 19:134-9. doi: $10.1177 / 1043659607313071$ 
182. Nilsson JE, Brown C, Russell EB, Khamphakdy-Brown S. Acculturation, partner violence, and psychological distress in refugee women from Somalia. J Interpers Violence (2008) 23:1654-63. doi: 10.1177/08862605083 14310

183. Norris AE, Aroian KJ, Norris AE, Aroian KJ. Avoidance symptoms and assessment of posttraumatic stress disorder in Arab immigrant women. $J$ Trauma Stress. (2008) 21:471-8. doi: 10.1002/jts.20363

184. Schwartz K, Fakhouri M, Bartoces M, Monsur J, Younis A. Mammography screening among Arab American women in metropolitan Detroit. J Immigr Minor Health (2008) 10:541-9. doi: 10.1007/s10903-008-9140-8

185. Shah SM, Ayash C, Pharaon NA, Gany FM. Arab American immigrants in New York: health care and cancer knowledge, attitudes, and beliefs. J Immigr Minor Health (2008) 10:429-36. doi: 10.1007/s10903-007-9106-2

186. Weglicki LS, Templin TN, Rice VH, Jamil H, Hammad A, Weglicki LS, et al. Comparison of cigarette and water-pipe smoking by Arab and non-Arab-American youth. Am J Prev Med. (2008) 35:334-9. doi: 10.1016/j.amepre.2008.06.037

187. Abdulrahim S, Baker W. Differences in self-rated health by immigrant status and language preference among Arab Americans in the Detroit Metropolitan Area. Soc Sci Med. (2009) 68:2097-103. doi: 10.1016/j.socscimed.2009.04.017

188. Arfken CL, Kubiak SP, Farrag M. Acculturation and polysubstance abuse in Arab-American treatment clients. Transcult Psychiatry (2009) 46:608-22. doi: $10.1177 / 1363461509351364$

189. Dallo FJ, Al Snih S, Ajrouch KJ. Prevalence of disability among US- and foreign-born Arab Americans: results from the 2000 US Census. Gerontology (2009) 55:153-61. doi: 10.1159/000151538

190. Hobbs RD, Habib Z, Alromaihi D, Idi L, Parikh N, Blocki F, et al. Severe vitamin D deficiency in Arab-American women living in Dearborn, Michigan. Endocr Pract. (2009) 15:35-40. doi: 10.4158/EP.15.1.35

191. Johnson CE, Ali SA, Shipp MPL. Building community-based participatory research partnerships with a somali refugee community. Am J Prev Med. (2009) 37(6, Suppl. 1):S236. doi: 10.1016/j.amepre.2009. 09.036

192. Ness SM. Pain expression in the perioperative period: insights from a focus group of Somali women. Pain Manag Nurs. (2009) 10:65-75. doi: 10.1016/j.pmn.2008.05.001

193. Ramaswamy V, Aroian KJ, Templin T. Adaptation and psychometric evaluation of the multidimensional scale of perceived social support for Arab American adolescents. Am J Community Psychol. (2009) 43:49-56. doi: $10.1007 / \mathrm{s} 10464-008-9220-\mathrm{x}$

194. Wrobel NH, Farrag MF, Hymes RW. Acculturative stress and depression in an elderly Arabic sample. J Cross Cult Gerontol. (2009) 24:273-90. doi: 10.1007/s10823-009-9096-8

195. Kira IA, Lewandowski L, Templin T, Ramaswamy V, Ozkan B, Mohanesh J. The effects of perceived discrimination and backlash on Iraqi refugees' mental and physical health. J Muslim Ment Health (2010) 5:59-81. doi: 10.1080/15564901003622110

196. El-Sayed AM, Tracy M, Scarborough P, Galea S. Suicide among ArabAmericans. PLoS ONE (2011) 6:e14704. doi: 10.1371/journal.pone.0014704

197. Arnetz J, Rofa Y, Arnetz B, Ventimiglia M, Jamil H. Resilience as a protective factor against the development of psychopathology among refugees. J Nerv Ment Dis. (2013) 201:167-72. doi: 10.1097/NMD.0b013e3182848afe

198. Kira IA, Lewandowski L, Ashby JS, Templin T, Ramaswamy V, Mohanesh J. The traumatogenic dynamics of internalized stigma of mental illness among arab American, Muslim, and Refugee Clients. J Am Psychiatr Nurses Assoc. (2014) 20:250-66. doi: 10.1177/1078390314542873

199. Bettmann JE, Penney D, Clarkson Freeman P, Lecy N. Somali refugees' perceptions of mental illness. Soc Work Health Care (2015) 54:738-57. doi: 10.1080/00981389.2015.1046578

200. Kulwicki A, Ballout S. Post traumatic stress disorder (Ptsd) in arab American refugee and recent immigrant women. J Cult Divers (2015) 22:9-12.

201. Pratt R, Fadumo A, Hang M, Osman S, Raymond N. Perceptions of mental illness in the Somali community in Minnesota. Int J Migr Health Soc Care (2016) 12:16-25. doi: 10.1108/IJMHSC-04-2014-0011

202. Samari G. Cross-border ties and Arab American mental health. Soc Sci Med. (2016) 155:93-101. doi: 10.1016/j.socscimed.2016.03.014
203. Salman KF. Health beliefs and practices related to cancer screening among arab muslim women in an urban community. Health Care Women Int. (2012) 33:45-74. doi: 10.1080/07399332.2011.610536

204. Wieland M, Morrison T, Cha S, Rahman A, Chaudhry R. Diabetes care among somali immigrants and refugees. J Community Health (2012) 37:6804. doi: 10.1007/s10900-011-9499-7

205. Salinitri FD, Pinelli NR, Martin ET, Jaber LA. Insulin sensitivity and secretion in arab americans with glucose intolerance. Diabetes Technol Ther. (2013) 15:1019-24. doi: 10.1089/dia.2013.0045

206. Njeru JW, Hagi-Salaad MF, Haji H, Cha SS, Wieland ML. Diabetes health literacy among somali patients with diabetes mellitus in a US primary care setting. J Racial Ethn Health Disparities (2016) 3:210-6. doi: 10.1007/s40615-015-0129-4

207. Abdulrahim S, Ajrouch K. Social and cultural meanings of self-rated health: Arab immigrants in the United States. Qual Health Res. (2010) 20:1229-40. doi: $10.1177 / 1049732310371104$

208. Jamil H, Nassar-McMillanb S, Lambert R, Wangd Y, Ager J, Arnetz B. Pre- and post-displacement stressors and time of migration as related to self-rated health among Iraqi immigrants and refugees in Southeast Michigan. Med Confl Surviv. (2010) 26:207-22. doi: 10.1080/13623699.2010. 513655

209. Ogunleye O, Shelton JA, Ireland A, Glick M, Yeh J. Preferences for labor and delivery practices between pregnant immigrants and U.S.-born patients: a comparative prospective antenatal survey study. J Natl Med Assoc. (2010) 102:481-4. doi: 10.1016/S0027-9684(15)30555-1

210. Pavlish CL, Noor S, Brandt J. Somali immigrant women and the American health care system: discordant beliefs, divergent expectations, and silent worries. Soc Sci Med. (2010) 71:353-61. doi: 10.1016/j.socscimed.2010.04.010

211. Qahoush R, Stotts N, Alawneh MS, Froelicher ES. Physical activity in Arab women in Southern California. Eur J Cardiovasc Nurs. (2010) 9:263-71. doi: 10.1016/j.ejcnurse.2010.03.002

212. Rothe E, Holt C, Kuhn C, McAteer T, Askari I, O’Meara M, et al. Barriers to outdoor physical activity in wintertime among somali youth. J Immigr Minor Health (2010) 12:726-36. doi: 10.1007/s10903-009-9287-y

213. Sarsour L, Tong VS, Jaber O, Talbi M, Julliard K. Health assessment of the arab american community in southwest brooklyn. J Community Health (2010) 35:653-9. doi: 10.1007/s10900-010-9260-7

214. Steinman L, Doescher M, Keppel GA, Pak-Gorstein S, Graham E, Haq $A$, et al. Understanding infant feeding beliefs, practices and preferred nutrition education and health provider approaches: an exploratory study with Somali mothers in the USA. Matern Child Nutr. (2010) 6:67-88. doi: 10.1111/j.1740-8709.2009.00185.x

215. Ayash C, Axelrod D, Nejmeh-Khoury S, Aziz A, Yusr A, Gany F. A community intervention: AMBER: Arab American breast cancer Education and referral program. J Immigr Minor Health (2011) 13:1041-7. doi: 10.1007/s10903-011-9481-6

216. Brittin HC, Obeidat BA. Food practices, changes, preferences and acculturation of Arab students in US universities. Int J Consum Stud. (2011) 35:552-9. doi: 10.1111/j.1470-6431.2011.01023.x

217. El-Sayed AM, Tracy M, Scarborough P, Galea S. Ethnic inequalities in mortality: the case of Arab-Americans. PLoS ONE (2011) 6:e29185. doi: 10.1371/journal.pone.0029185

218. Flynn PM, Foster EM, Brost BC. Indicators of acculturation related to somali refugee women's birth outcomes in minnesota. J Immigr Minor Health (2011) 13:224-31. doi: 10.1007/s10903-009-9289-9

219. Gurnah K, Khoshnood K, Bradley E, Yuan C. Lost in translation: reproductive health care experiences of somali bantu women in Hartford, Connecticut. J Midwifery Womens Health (2011) 56:340-6. doi: 10.1111/j.1542-2011.2011.00028.x

220. Nriagu J, Senthamarai-Kannan R, Jamil H, Fakhori M, Korponic S. Lead poisoning among Arab American and African American children in the Detroit metropolitan area, Michigan. Bull Environ Contam Toxicol. (2011) 87:238-44. doi: 10.1007/s00128-011-0346-4

221. Padela AI, Rasheed S, Warren GJW, Choi H, Mathur AK. Factors associated with positive attitudes toward organ donation in Arab Americans. Clin Transplant. (2011) 25:800-8. doi: 10.1111/j.1399-0012.2010. 01382.x 
222. Salem W, Flynn P, Weaver A, Brost B. Fertility After Cesarean Delivery Among Somali-Born Women Resident in the USA. J Immigr Minor Health (2011) 13:494-9. doi: 10.1007/s10903-010-9362-4

223. Smith BD, Silk K. Cultural competence clinic: an online, interactive, simulation for working effectively with arab american muslim patients. Acad Psychiatry (2011) 35:312-6. doi: 10.1176/appi.ap.35.5.312

224. Benbenek MM, Garwick AW. Enablers and barriers to dietary practices contributing to bone health among early adolescent Somali girls living in Minnesota. J Spec Pediatr Nurs. (2012) 17:205-14. doi: 10.1111/j.1744-6155.2012.00334.x

225. Dallo F, Schwartz K, Ruterbusch J, Booza J, Williams D. Mortality Rates Among Arab Americans in Michigan. J Immigr Minor Health (2012) 14:23641. doi: 10.1007/s10903-011-9441-1

226. Devlin JT, Dhalac D, Suldan AA, Jacobs A, Guled K, Bankole KA. Determinants of physical activity among somali women living in maine. $J$ Immigr Minor Health (2012) 14:300-6. doi: 10.1007/s10903-011-9469-2

227. Hill N, Hunt E, Hyrkäs K. Somali Immigrant Women's Health Care experiences and beliefs regarding pregnancy and birth in the United States. $J$ Transcult Nurs. (2012) 23:72-81. doi: 10.1177/1043659611423828

228. Jadalla A, Lee J. The relationship between acculturation and general health of Arab Americans. J Transcult Nurs. (2012) 23:159-65. doi: $10.1177 / 1043659611434058$

229. Tami SH, Reed DB, Boylan M, Zvonkovic A. Assessment of the effect of acculturation on dietary and physical activity behaviors of Arab mothers in Lubbock, Texas. Ethn Dis. (2012) 22:192-7.

230. Beatson JE. Supporting refugee Somali Bantu mothers with children with disabilities. Pediatr Nurs. (2013) 39:142-5.

231. Caron R, Tshabangu-Soko T, Finefrock K. Childhood lead poisoning in a somali refugee resettlement community in new hampshire. J Community Health (2013) 38:660-9. doi: 10.1007/s10900-013-9661-5

232. Clarkson Freeman PA, Penney DS, Bettmann JE, Lecy N. The intersection of health beliefs and religion among somali refugees: a qualitative study. J Relig Spiritual Soc Work (2013) 32:1-13. doi: 10.1080/15426432.2013. 749141

233. Deckys C, Springer P. The elderly somali bantu refugees' adjustment to american healthcare. Online J Cult Competence Nurs Healthc. (2013) 3:3-15. doi: 10.9730/ojccnh.org/v3n1a1

234. Finkton D, El-Sayed A, Galea S. Infant mortality among arabamericans: findings from the arab-american birth outcomes study. Matern Child Health J. (2013) 17:732-45. doi: 10.1007/s10995-0121049-0

235. Geltman PL, Adams JH, Cochran J, Doros G, Rybin D, Henshaw M, et al. The impact of functional health literacy and acculturation on the oral health status of Somali refugees living in Massachusetts. Am J Public Health (2013) 103:1516-23. doi: 10.2105/AJPH.2012.300885

236. Haddad L, Corcoran J. C ulturally tailored smoking cessation for arab american male smokers in community settings: a pilot study. Tob Use Insights. (2013) 6:17-23. doi: 10.4137/TUI.S11837

237. Henning-Smith C, Shippee TP, McAlpine D, Hardeman R, Farah F. Stigma,discrimination, or symptomatologydifferences in self-reported mental health between us-born and somalia-born black Americans. Am J Public Health (2013) 103:861-7. doi: 10.2105/AJPH.2012.301184

238. Talaat N, Harb W. Reluctance to screening colonoscopy in Arab Americans: a community based observational study. J Community Health (2013) 38:61925. doi: 10.1007/s10900-013-9688-7

239. Alkhateeb HM, Abushihab EF. Self-esteem and Arab-American elementary students. Psychol Rep. (2014) 115:805-9. doi: 10.2466/07.11.PRO.115c27z9

240. Bekhet AK, Zauszniewski JA. Individual characteristics and relocation factors affecting adjustment among relocated american and egyptian older adults. Issues Ment Health Nurs. (2014) 35:80-7. doi: 10.3109/01612840.2013.842620

241. Filippi M, Faseru B, Baird M, Ndikum-Moffor F, Greiner K, Daley C. A pilot study of health priorities of somalis living in kansas city: laying the groundwork for CBPR. J Immigr Minor Health (2014) 16:314-20. doi: $10.1007 /$ s10903-012-9732-1

242. Haddad L, El-Shahawy O, Ghadban R. Comparison of barriers to cessation among Arab American smokers of cigarettes and waterpipe. Int J Environ Res Public Health (2014) 11:9522-31. doi: 10.3390/ijerph110909522
243. Hearst MO, Kehm R, Sherman S, Lechner KE. increasing fruit and vegetable consumption and offerings to somali children: The FAV-S pilot study. J Prim Care Community Health (2014) 5:139-43. doi: 10.1177/2150131913513269

244. Kira IA, Lewandowski L, Ashby JS, Somers C, Chiodo L, Odenat L. Does bullying victimization suppress IQ? the effects of bullying victimization on IQ in Iraqi and African American Adolescents: a traumatology perspective. J Aggress Maltreat Trauma (2014) 23:431-53. doi: 10.1080/10926771.2014.904463

245. Perumalswami PV, Miller FD, Orabee H, Regab A, Adams M, Kapelusznik L, et al. Hepatitis $\mathrm{C}$ screening beyond CDC guidelines in an Egyptian immigrant community. Liver Int. (2014) 34:253-8. doi: 10.1111/liv.12259

246. Pooler J, Gleason SF. Comparison of WIC benefit redemptions in michigan indicates higher utilization among Arab American Families. J Nutr Educ Behav. (2014) 46:(Suppl. 3):S45-52. doi: 10.1016/j.jneb.2014.02.019

247. Dallo FJ, Kindratt TB. Disparities in preventive health behaviors among non-Hispanic White men: heterogeneity among foreign-born Arab and European Americans. Am J Mens Health (2015) 9:124-31. doi: $10.1177 / 1557988314532285$

248. Elsouhag D, Arnetz B, Jamil H, Lumley M, Broadbridge C, Arnetz J. factors associated with healthcare utilization among arab immigrants and iraqi refugees. J Immigr Minor Health (2015) 17:1305-12. doi: 10.1007/s10903-014-0119-3

249. Goforth AN, Pham AV, Oka ER. Parent-child conflict, acculturation gap, acculturative stress, and behavior problems in Arab American Adolescents. J Cross Cult Psychol. (2015) 46:821-36. doi: 10.1177/0022022115 585140

250. Housey M, DeGuire P, Lyon-Callo S, Wang L, Marder W, McCune WJ, et al. Incidence and prevalence of systemic lupus erythematosus among Arab and Chaldean Americans in southeastern Michigan: the Michigan Lupus Epidemiology and Surveillance Program. Am J Public Health (2015) 105:74. doi: 10.2105/AJPH.2014.302423

251. Jadalla AA, Hattar M, Schubert CC. Acculturation as a predictor of health promoting and lifestyle practices of Arab Americans: a Descriptive Study. J Cult Divers. (2015) 22:15-22.

252. Kassem NOF, Kassem NO, Jackson SR, Daffa RM, Liles S, Hovell MF. Arabamerican hookah smokers: initiation, and pros and cons of hookah use. Am J Health Behav. (2015) 39:680-7. doi: 10.5993/AJHB.39.5.10

253. Mikal JP, Woodfield B. Refugees, post-migration stress, and internet use: a qualitative analysis of intercultural adjustment and internet use among iraqi and sudanese refugees to the United States. Qual Health Res. (2015) 25:1319-33. doi: 10.1177/1049732315601089

254. Murray KE, Mohamed AS, Dawson DB, Syme M, Abdi S, Barnack-Taviaris J. Somali perspectives on physical activity: photovoice to address barriers and resources in San Diego. Prog Commun Health Partnersh (2015) 9:83-90. doi: $10.1353 / \mathrm{cpr} .2015 .0011$

255. Odunukan OW, Abdulai RM, Hagi Salaad MF, Lahr BD, Flynn PM, Wieland ML. Provider and interpreter preferences among somali women in a primary care setting. J Prim Care Community Health (2015) 6:105-10. doi: $10.1177 / 2150131914552846$

256. Salman K, Resick L. The Description of health among iraqi refugee women in the United States. J Immigr Minor Health (2015) 17:1199-205. doi: 10.1007/s10903-014-0035-6

257. Wieland M, Tiedje K, Meiers S, Mohamed A, Formea C, Ridgeway J, et al. Perspectives on physical activity among immigrants and refugees to a small urban community in Minnesota. J Immigr Minor Health (2015) 17:263-75. doi: 10.1007/s10903-013-9917-2

258. Dallo F, Ruterbusch J, Kirma J, Schwartz K, Fakhouri M. A Health profile of arab Americans in Michigan: a novel approach to using a hospital administrative database. J Immigr Minor Health (2016) 18:1449-54. doi: 10.1007/s10903-015-0296-8

259. Dallo FJ, Kindratt TB. Disparities in chronic disease prevalence among non-hispanic whites: heterogeneity among foreign-born arab and European Americans. J Racial Ethn Health Disparities (2016) 3:590-8. doi: 10.1007/s40615-015-0178-8

260. Goforth AN, Pham AV, Chun H, Castro-Olivo SM, Yosai ER. Association of acculturative stress, Islamic practices, and internalizing symptoms among Arab American adolescents. Sch Psychol Q. (2016) 31:198-212. doi: $10.1037 /$ spq0000135 
261. Lincoln AK, Lazarevic V, White MT, Ellis BH. The impact of acculturation style and acculturative hassles on the mental health of somali adolescent refugees. J Immigr Minor Health (2016) 18:771-8. doi: 10.1007/s10903-015-0232-y

262. McClelland ML, Weekes CVN, Bazzi H, Warwinsky J, Abouarabi W, Snell F, et al. Perception of Obesity in AfricanAmerican and Arab-American Minority Groups. I Racial Ethn Health Disparities (2016) 3:160-7. doi: 10.1007/s40615-0150127-6

263. Missal B, Clark C, Kovaleva M. Somali immigrant new mothers' childbirth experiences in Minnesota. J Transcult Nurs. (2016) 27:359-67. doi: $10.1177 / 1043659614565248$

264. Padela AI, Vu M, Muhammad H, Marfani F, Mallick S, Peek $\mathrm{M}$, et al. Religious beliefs and mammography intention: findings from a qualitative study of a diverse group of American Muslim women. Psychooncology (2016) 25:1175-82. doi: 10.1002/ pon. 4216
265. Vu M, Azmat A, Radejko T, Padela AI. Predictors of delayed healthcare seeking among American Muslim Women. J Womens Health (2016) 25:586-93. doi: 10.1089/jwh.2015.5517

266. Dallo FJ. Health Disparities. New York, NY: Handbook of Arab American Psychology; Routledge (2015).

Conflict of Interest Statement: The authors declare that the research was conducted in the absence of any commercial or financial relationships that could be construed as a potential conflict of interest.

Copyright (C) 2018 Abuelezam, El-Sayed and Galea. This is an open-access article distributed under the terms of the Creative Commons Attribution License (CC BY). The use, distribution or reproduction in other forums is permitted, provided the original author(s) and the copyright owner(s) are credited and that the original publication in this journal is cited, in accordance with accepted academic practice. No use, distribution or reproduction is permitted which does not comply with these terms. 